\title{
From Persons to Hospital Cases: The Rise of Hospital Medicine and the Calcutta Medical College in India
}

\author{
Jayanta Bhattacharya*
}

(Received 24 February 2014)

\begin{abstract}
From today's medical perspective, there is little mention of case records in India. With the arrival of Western medicine in India in the 18th century, there emerged the practice of keeping case records in hospitals erected by European powers. It did not automatically lead to hospital medicine, which required physical examination, autopsy, statistics and museums for preserving the cases. The foundation of the Calcutta Medical College in 1835, built on the model of University College of London, ushered into it. Serial experiments in Calcutta like producing native dressers in Madras establishments, the founding of the Native Medical Institution (1822) for native doctors, introduction of medical classes at the Sanskrit College and Madrassa etc. preceded it. The 18th-19th century case records were of European soldiers by European doctors. Almost every surgeon had charge of 700 patients. They would keep a regular diary of cases. In 1826, Tytler had introduced keeping case records in Persian by the NMI students. The conceptual basis of clinical case is the ordering of its facts by the agency of time. Its material dimension is the transcription of this evidence in written form, thereafter embodied as a medical record of observed events. After 1826, the keeping of case records was internalized by Indian students. Till then they did not perform dissection beyond zootomy. Hence the cases were actually records of symptoms, instead of signs which were to be confirmed through pathological anatomy. The transition was made possible through CMC. In CMC, students were to examine patients at the bedside, perform dissection after his/her death and keep records which were to be produced during examination. At the same time, they had to keep records of both medical and surgical cases, and the reports of experimentation the Jennerian vaccine and various drugs - both European and indigenous - on patients. Along with CMC, through the Medical and Physical Society of Calcutta (1823) and its journal Transactions of the Medical and Physical Society of Calcutta (1825) circulation of medical, surgical, and pharmaco-botanical knowledge throughout India and to Europe became practicable. The introduction of anatomical dissection secularized both the notion of the body and medical education stripped off from caste prejudice and parochial hierarchy. The hospital case records became a materiality through internalization of hospital medicine in its full gamut by Indians like S G Chuckerbutty.
\end{abstract}

Key words: Anatomy, Calcutta Medical College, Case records, Dissection, Experimentations, Hospital medicine, India, S. G. Chuckerbutty

\section{INTRODUCTION}

In 1743, Lawrence Heister's Latin work on surgery was translated into English. He divided surgery into two parts - (a) theoretical or medical surgery and (b) practical surgery. He wrote,
"Whoever desires to be a perfect Surgeon, must be a thorough Master of his Profession under both heads, as a Science and as an Art: and in such a manner that the theoretical Part, or knowledge of Elements, (in which Anatomy claims the first

*Independent Scholar, Tulsitala, P.O: Raiganj, Dist: Uttar Dinajpur-733134, West Bengal, Email: drjayanta@gmail.com 
place) should precede the exercise of the art" (Heister, 1743, p. 3 and Allbutt, 1905).

Anyone, who is acquainted with classical texts of Āyurveda, will find a similar tenor in the Suśruta-Samhitā (SS). In Sharma's translation, “Of all the eight parts of Āyurveda, this verily is highly recognized because of immediate operation, application of blunt and sharp instruments, caustic alkali and cautery are being common in all parts" (SS. ed \& tr, Sharma, p. 14; Sū. I.18).

Moreover, "The quack who is ignorant in practical application of unction etc. and excision etc. kills the people out of greed due to negligence of the state” (SS. ed \& tr, Sharma, p. 14; Sū. III.42).

On the contrary, "One who is expert in both (theory and practice) and intelligent is capable of accomplishing his objects as the two-wheeled chariot successfully carries on its job in the battle" (SS. ed \& tr, Sharma, p. 14; Sū. III.43).

Even in William Hunter's “Two Introductory Lectures" the description of anatomical learning seems quite close to Suśruta's description, "Anatomy is the art of examining animal bodies by dissection. It teaches the structure and functions of those bodies, and shews nearly on what life and health depend. When these are well understood, a great step is made towards the knowledge and cure of diseases" (Hunter, 1784, p. 3).

Heister also observed in his work, "Much of the greater part of the modern Physicians have been content with the knowledge of the former part of Surgery, leaving the execution of the latter, which is much to be lamented, to unskillful Quacks and Mountebanks" (Heister, 1743, p. 3). Interestingly, Robert Southey's Letters is replete with information and evidence of quackery, charms and supernatural practices. In his observation, "quackery is carried to greater perfections of villainy here than in any other part of the world. Sickness humbles the pride of man; it forces upon him a sense of his own weakness, and teaches him to feel his dependence upon unseen Powers: that therefore which makes wise men devout, makes the ignorant superstitious" (Southey, 1814, p. 284).

Elsewhere, Southey noticed, "The abracadabra of the old heretics was lately in use as a charm for the ague, and probably still is where ague is to be found, for that disease has almost wholly disappeared within the last generation. For warts there are manifold charms" (Southey, 1814, p. 282). He noted that any scientific discovery was immediately seized by some of the quacks, the most eminent of whom was a 'Doctor Graham" (Southey, 1814, p. 288). Galvanism too, like electricity, "was no sooner discovered than it was applied to purposes of quackery" (Southey, 1814, p. 290). He appears to indignantly note, “The Scotch Universities also sell them degrees in medicine without the slightest examination" (Southey, 1814, p. 301). He made a trenchant observation, "Government gives an indirect sort of sanction to these worst of all impostors. They enter the receipt of their medicines as a discovery, and for the payment of about 100/. sterling, take out a privilege, which is here called a patent, prohibiting all other persons from compounding the same...” (Southey, 1814, p. 300-301).

Coming back to anatomical knowledge and its learning process, the façade of apparent similitude between Europe and Indian text seems soon to dissolve. To follow Heister's account,

\footnotetext{
if any Surgeon has been long in Practice $\ldots$ and is not thoroughly versed in Anatomy, and the Institutions of Surgery, his actions are always doubtful and uncertain, and are ever obnoxious to multiplicity of dangers. Therefore it is necessary for the good Surgeon to be a thorough Master of both; but he that at the same time understands the other branches of Physic, as many amongst the ancient and modem Physicians have done, is by so much the greater and more perfect Surgeon (Heister, 1743, p. 3).
} 
We should take into account the importance of the "Institutions of Surgery", which becomes an undeniable materiality of modern anatomy and surgery.

It should be noted that in Hunterian (or anatomist's) description an individual human body remains at the center-stage of the narrative. Hunter had told his students, "Anatomy is the basis of Surgery, it informs the head, guides the hand, and familiarizes the heart to a kind of necessary inhumanity” (Gawande, 2012, p. 1717). Temkin comments, "It will then be agreed that the surgeons studied anatomy and that they enriched medical literature with the discoveries and observations of use to every medical man” (Temkin, 1977, p. 493). Thus, anatomy and the new surgical practices consequent upon it became equated with modernity too. And "the dissector claimed the status of an epistemologically privileged cultural arbiter” (Sappol, 2004, p. 3). Not only so, anatomical dissection, wax models, schematic chalk drawings from the classroom, as argued by Berkowitz, formed several things, "Nature, a representation of Nature, and a representation of a particular argument about how the natural world was constituted” (Berkowitz, 2012, p. 3). And, in all these acts, unlike India, seeing was privileged over reading and memorizing.

For the late eighteenth- and early nineteenth-century anatomists, displays constituted a form of reasoning and a way of teaching (Berkowitz, 2012, p. 29). We shall find this praxis during the period of the Native Medical Institution (NMI). All these characteristics were carried over to India.

Edelstein draws our attention to the fact that anatomy had no closer relationship "to ancient medicine than had, for instance, botany or zoology, for there was no necessity to study the internal structure of the organism ... In antiquity, knowledge of the body is never exclusively professional knowledge, as it is now" (Edelstein, 1994, pp. 260-61). Moreover, in a more recent observation, "No person exists without others; there is no consciousness without a consciousness of others, no speaker without a hearer ... thought that does not somehow encompass others" (Cassel, 1982, p. 642).

In Meuelnbeld's translation, "With respect to their division into atoms (paramānu), the component parts of the body are countless, because these atoms are present in very large numbers, of very minute size and incomprehensible. Conjunction (samyoga) and disjunction (vibhāga) of the atom is caused by vāyu and and the own nature (svabhāva) of karman (movement)” (Meulenbeld, 1999, p. 46).

Wujastyk convincingly informs us about so many different types of bodies, including different types of medical bodies found in premodern India (Wujastyk, 2009, pp. 189-228). He notes, "In fact, all Āyurvedic manuscripts the author has studied have been empty of accompanying illustrative materials. There are small sketches of chemical apparatuses in some alchemical manuscripts, notably those of the Rasendramangala and some of the Rasaratnākara. But no single manuscript the author have seen contains even so much as an anatomical sketch, a line drawing for surgical guidance, or any other visual representation of the medical body” (Wujastyk, 2009, p. 207). The only exception being the famous "āyurvedic man". After the foundation of the NMI in Calcutta in 1822, following Wujastyk, “The Indian response to these new foreign influences was variously accommodation, adaptation, absorption, and, later, syncretism” (Wujastyk, 2009, p. 212). Illsutrations of the Âyuvedic body with anatomical import began to appear in print from the late nineteenth century. Even then, cogently, Wujastyk does not claim of any bodily image found in India containing three-dimensional spatial sense.

At this juncture, it may be useful to think of Meulenbeld. He reminds us that the renaissance 
of Āyurveda since the middle of the nineteenth century "led to the construction of a unitary model of Indian medicine, weaned from inconsistencies and untenable concepts ... The ancient terms for physiological and pathological processes, nosological entities etc., were diligently reinterpreted to bring them into line with terms derived from Western medicine" (Meulenbeld, 2008, p. 2).

Now, let us note that two important changes began to insinuate within the perception of medicine by the sixteenth century onwards. The notion of time was reconstituted along with the notion of three-dimensional space of the body. These two developments had a profound impact on the rise of modern medicine, otherwise may be called as 'hospital medicine', in India. The usual practice of recordkeeping activities since the beginning of colonial rule in India brought forth the absolute necessity of time and, simultaneously, the objects of which records were kept became the space where the new time-frame could be put in operation. Seen in this way, the body became the new space where the new notion of linear, scientific time found its full expression.

Alavi beautifully shows how, when the legitimating context of pre-colonial practioners of Unani medicine was lost, they "dispersed into qasbas and towns of the North Indian countryside, so did their new ideas and term (Alavi, 2007, p. 98). In the countryside, they presumably found their epistemological root too, which was severed at the NMI.

\section{Time, Space and Scientific Medicine against Indian Perspective (BHATTACHARYA, 2008, PP. 163-210)}

While tracing the social meaning of time related to medicine, Lee notes that the Renaissance notion of the perfectibility of humankind, the importance of individuality, and the possibility of progress originated with a sense of time as a straight line leading "an end of time" and apocalypse, rather than a circle (Lee, 2000, pp. 11-17). This is relevant for medical perception in India. Kern relates the discovery of private time to the understanding of modern medicine (Kern, 2001, pp. 3-9). In antiquity, e.g. Greek medicine, "The basic connection of illness with the change of the seasons made temporal ordering of clinical cases logical” (Reiser, 2000, p. 36).

Thompson insightfully informs us, "It is commonplace that the years between 1300 and 1650 saw within the intellectual culture of Western Europe important changes in the apprehension of time” (Thompson, 1967, p. 56). He puts forward the idea that industrialization and capitalism introduced a new time discipline which clearly departed from the perception of traditional time. In this distinction was supposed "of course, the independent peasant or craftsman as referent” (Thompson, 1967, p. 61). Individuals, as distinct from socially embedded persons, began to play their prime role. As is obvious, medicine was not immune to these changes.

But in Indian perspective, as Thapar argues, "Cosmological time did not debar other forms of time reckoning, perhaps more realistic and therefore liable to be subsumed in cosmological time” (Thapar, 2006, p. 29). Thus, in Indian medical practice the notion of time is basically derived from the cosmological time frame. In Nakamura's observation, “time as a fundamental principle is understood cyclically, perhaps reflecting agricultural man's sensitivity to the pattern of recurring seasons. A linear, historical sense of time like that found in the Old Testament or the Koran never developed in India” (Nakamura, 1992, p. 64).

David Price translated Mualijāt-i-DārāShekohí - "a work of no common magnitude or importance” (Price, 1835, pp. 32-56). In that treatise, time was conceived "as the obstetric medium through which the varieties of vegetables 
and animal creation throughout the universe are ushered into life, and made to appear under particular forms; such forms being prior to element which belongs to nature... Time again is included in duration” (Price, 1835, p. 34). No action or motion could remain unconnected with time "time is a thing which moves in two separate sections, that which is past and that which is not yet come; and between the two there is an interval which is incapable of division - like the line between the sun and the shade, which belongs neither to sun nor shade” (Price, 1835, p. 34).

Unlike this notion, in the $S S$, " $k \bar{a} l a$ (time) is (all powerful), self-emerged and without beginning, middle and end. Thereon are dependent derangement and excellence of rasa (nourishing sap) and also life and death of men. It is ' $k \bar{a} l a$ ' as it does not stay for even a minute fraction; or seizes or leads living being to death” (SS, ed \& tr, Sharma, p. 73; Sū, 6.3).

Again, "Of that having the identity as samvatsara (year), Lord Sun makes further divisions into akșinimeșa (blinking of eye), kāṣth $\bar{a}$, kāla, muhūrta, day and night, fortnight, month, season, courses, year and yuga by his specific movements” (SS, ed \& tr, Sharma, p. 74; Sū, 6.4). Then differentiations are elaborated among aksinimeșa, kāṣthāa, kāla, muhūrta and fortnight (Sū, 6.5).

As Dasgupta points out, in the $S S$, the causes of things are sixfold of which time $(k \bar{a} l a)$ comprises the third one (Dasgupta, 1991, p. 372). Similar characteristics are also found in the Caraka-Samhitā (CS) (Dasgupta, 1991, pp. 369370). In both the cases time is regarded as an inherent quality of a thing, not any entity outside the body.

In the $C S$, " $k \bar{a} l a$ is eternally moving (time) as well as conditional. The conditional one related to disorder while the eternally moving one to seasonal stability” (CS, tr, Sharma, p. 306; CS.Vi. 1.21).
In another place, "kāla (time) is transformation” (Vi, 8.76) and "deśa (place) is location” (CS, tr, Sharma, p. 370; Vi, 8.75).

Here time denotes both which flows perpetually (nityaga) and as a "phase" (avasthika). The perpetual time (nityaga) makes sense of the cycles of the seasons (samvatasara). "It is a subjective time as perceived by the patient and on which the physician is capable of acting by prescribing a treatment and a diet which are both appropriate to the season and to the state of development of the disease, in order to restore the balance between the patient and his environment" (Mazars, 2006, pp. 28-29). "This conception of time”, Mazars argues, "is at the root of a certain number of notions which, in Āyurveda, are related to biological rhythms.” (Mazars, 2006, p. 29). In his masterly exposition, Meulenbeld describes the course and development of a disease. The course of a disease in Indian medicine is thought of as a continuous process of development.

\begin{abstract}
A disease is something that gradually is made manifest. Prodoromes (pūrvarūpa) develop into full-fledged symptoms (rūpa). Secondary affections (upadrava) are consequences of the basic morbid process. At the end of the process recovery takes place or fatal signs (arișta) appear, foreboding death. The stages of this evolutionary process are delineated. Each stage is characterized by a cluster of signs. In many cases the enumeration of these signs occurs in the form of verses, more easy to remember than statements in prose.
\end{abstract}

(Meulenbeld, 2008, p. 612).

To note, such a notion of etiopathogenesis related to disease development does not bear any semblance with modern anatomy, pathology, physiology or organ localization of disease. It has got its own explanatory model for the explanation of disease causation. Scientific linear time does not signify anything in this perception, nor the three-dimensional bodily space. It is situated in the frame of macrocosm-microcosm 
interrelationship and their ensuing harmony. It is situated beyond the time-space frame of postindustrial Europe.

In this explanatory model, no individual cases can be thought of. "The conceptual basis of clinical case is the ordering of its facts by the agency of time. Its material dimension is the transcription of this evidence in written form, thereafter embodied as a medical record of observed events” (Reiser, 2000, p. 31). After the colonization of India the subjective experience of "life-cycle time could now be projected into a new epistemic domain rendering it objective, measurable and linear" (Kalpagam, 1999, p. 149). Sarkar observes that disciplinary time had evolved in Europe for some five hundred years. But it was "particularly abrupt and imposed innovation in India” (Sarkar, 2002, p. 309). Among so other socially and politically important institutions, hospitals were an important area set into clocktime rhythm. "Colonial rule telescoped the entire process for India within one or two generations" (Sarkar, 2002, p. 309).

Moreover, on knowing the fact that the population "could be spatially delineated, enumerated and classified according to afflictions" and causes could be established scientifically, "the methods of intervention could be applied" (Kalpagam, 1999, p. 149). This is what happened in the world of medicine. Time and space (or, so to speak, Foucauldian tertiary spatialization related to bodily and social space) became the two important constitutive features of a patient in hospital.

In European medical tradition, unlike India, keeping case records of diseases was a common practice. In this practice, each and every person with his body was singled out as an individual case, not as a socially embodied collective without individual histories of cases recorded. Galen used to keep his patients' case histories in a regular manner. The following tables will show it (Horstmanshoff and Schrijvers, 1995, pp. 90-91).

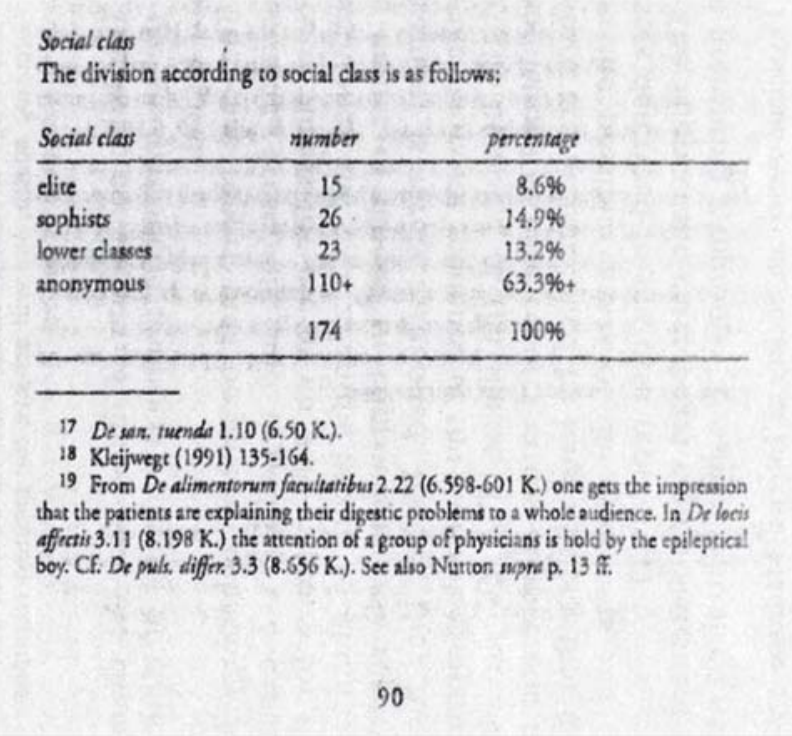

Suffice it to say, collected patient histories have been the stable centre of medical knowing. “In 1773 Fabry's 600 observations were published anew” (Hess and Mendelson, 2010, p. 289). It is a historical fact that recorded with "precision and reliability” in uniform tabular format, illness on paper invited their compilation into a synoptic tabular "Index of All Diseases from August 1790 to 1791" (Hess and Mendelson, 2010, p. 294). Unlike Indian experiences with hand-written manuscripts, in Europe paper played an important role in the recording of individual patient histories. Though the process of keeping case record started quite earlier (cf. Galen), paper became an important technology and technique of plotting clinical time-graph of an individual patient.

Additionally, Virchow emphasized, "What an effort it has cost us to overturn a system of humoral pathology secured by a thousand bonds of language and popular tradition" was supplemented by "a straightforward science based on direct experience with a realistic view of the tissues and their significance for pathology and therapy!” (Rather, 1958, p. 143). But, contrary to 
Virchow's belief, therapy did not run apace. "Pathology did not open the door to cures - hardly any eighteenth-century scientific advance helped heal the sick directly" (Porter, 1999, p. 266). It is perhaps best illustrated in a recent article. Until the 1950s, even in America, "the prevailing medical opinion well into the 1950s was that lowering of elevated blood pressure was detrimental because it would impair perfusion of vital organs and thereby increase the risk of cardiovascular and renal diseases. Three early pioneers who thought otherwise and aggressively pursued blood-pressure lowering were Walter Kempner, Reginald Smithwick, and Robert Wilkins. Each had a different approach: Kempner used dietary manipulation; Smithwick, surgery; and Wilkins, drug therapy" (Chobanian, 2009, p. 878).

European medicine, with these defining characteristics - new scientific knowledge of medicine, ambivalence and uncertainties ingrained in it, and excellence of surgical practice - arrived and consolidated itself in India. By the second quarter of the $19^{\text {th }}$ century, they had built up new Indian institutions which internalized the most advanced medical education and practices of European medical tradition.

This paper comprises three components (1) hospital medicine as it is known in recent scholarship since the late 1960s, (2) its Indian specificity, and (3) how different types of clinical case records were employed in the functioning and shaping of hospital medicine. The rise of hospital medicine in India and the emergence of clinical case records were, in some sense, mutually constitutive.

To note, Calcutta Medical College (CMC) was the crucible where the new system of medicine and the new collegiate system of medical education were successfully practiced and found their full expression.

\section{Hospital Medicine - Europe ANd India RECONSIDERED}

Hospital medicine, with its distinction from bedside medicine of earlier period, has attained attention of scholars since Ackerknecht coined the term in the late 1960s (Ackerknecht, 1967). “Ackerknecht offered a classification of the major stages in the history of Western medicine that proved to be remarkably influential” (Jacyna, 2006, p. 53). The three pillars of the new medicine - physical examination, autopsy, and statistics could be developed only in the hospital. It was the road to progress, achieved through large numbers of patients, carefully observed while alive, and carefully autopsied when dead. The same clinician who observed them during life performed the autopsy. The correlation of clinical data and autopsy findings, carried out on a vast scale, yielded magnificent progress. It gained further momentum after the publication of Jewson's now classic paper "The disappearance of the sick-man from medical cosmology, 17701870” (Jewson, 2009, p. 622-633). Jewson, among others, stressed on four specific issues - (1) "medical cosmology characteristic of Western European societies during the period 1770-1870", (2) "the universe of discourse of medical theory changed from that of integrated conception of the whole body to that of a network of bonds between microscopic particles", (3) social production of knowledge - raw material of production, and (4) a 'collegiate' system of educational control emerging within the community of medical investigators.

In his commentary on Jewson's paper, John Pickstone stresses that it may be profitable to think of historical analytical shift from a seriesmodel of successive types of medicine (bedside to hospital to laboratory to, now, techno-medicine) to a model of co-existence and inter-penetration of types where novel forms co-exist with the old one in contested cumulations (Pickstone, 2009, 
pp. 646-649). Talking about the early eighteenthcentury medical world, as Mary E. Fissel points out, overtly religious interpretations of illness would have been a useful, and common, explanatory resource. By the turn of the nineteenth century, the doctor has taken over, commandeered the patient's own words, almost unconsciously interpreting them and replacing them with his own medical equivalents (Fissel, 1991, pp. 92-109).

The patient's narrative was replaced by physical diagnosis and post-mortem dissection the cornerstone of hospital medicine. These two features were combined with the production of a new kind of statistics of disease and case records, and a collegiate system to perpetuate the new medicine for generations. Pathological anatomy became the hallmark or insignia of this new medicine. Somewhat similar to American scenario (Sappol, 2004), anatomical or pathological mode of expression became a pointer to modernity. In India, during the mid- $19^{\text {th }}$ century, British doctors "derived their claims to scientific objectivity and authority largely from their studies of morbid anatomy and their attempts to relate the state of diseased internal organs examined after death to the symptoms manifested externally during life.” (Arnod, 1993, p. 53).

We may note here that hospital medicine was basically a new medical cosmology characteristic of Western European societies evolving over a long period. By the time, some other social characteristics like secular nature of the state, the rise of the individual in society, new relations of productions related to the social production of knowledge, state-individual relationship, only to name a few, had already emerged in Europe. All these happenings had their cumulative effects on medicine. A common culture of medicine - sustained by the image of science as the universal agent of progress, and scientific medicine as its servant - became the hallmark of European empires throughout the world (MacLeod, 1988, p. 3).
Importantly, as hitherto described, both hospital medicine and case records were projects not arising out of historical development in India, they were rather grafted upon, and both were culturally circumscribed to a considerable extent. Recent scholarships argue that the new medicine emerged with their different characteristics both in Paris and London. However, as Risse observes,

\begin{abstract}
The most prominent outcome of the postRevolutionary era for French hospitals was the dominant presence of the medical profession and the execution of its pedagogical and research agendas in the wards. Particular styles of scientific thought are never generated in a vacuum. They emerge within specific cultural and institutional contexts that define and restrict the range of observations and discoveries.
\end{abstract}

(Risse, 1999, p. 309).

More specifically, with the rise of hospital medicine, patient's voice was lost and complete authority of the doctor over the patient became evident. But a different scenario emrges in Indian specificity. First, the caste superiority (Brahmins or Vaidyas) of the physician made his social authority acceptable to the extent of submerging patient's voice in a cosmos where hospital medicine was unthinkable. Second, patients' narratives and symptoms - not guided by extraction of 'signs' - were also taken into account by the physician. This unique situation is not commensurable with European experience.

Zimmermann gives an example of an eminent physician of Kerala,

\footnotetext{
He was visible for about four hours daily (6 a.m. to 10 a.m.) and he listened to what every patient had to say, quietly and attentively. No word was lost on him, for he was all attention ... When he had finished listening to the whole lot of the visitors of the day, he looked at his pupils or disciples who attended on him by turns, and pointing out to each patient he quoted the text which was to be prescribed in the
} 
particular case. He gave only the initial words of the text. The pupils immediately wrote out the full text of the prescription [...]. The written cadjan chits (palmleaves) of prescription were placed before the Musu and he would hand them over himself one by one to the patients concerned $[. .$.$] ...the Musu and his$ visitors would all sit on the floor... while those who would not sit with him would stand in the yard, or if they were of an inferior caste outside the enclosure, but all were before him in view and he would talk to all who had come..." (Zimmermann, 21 June 2013) (emphasis added).

As late as 1801, William Yates and Charles Maclean, while discussing their case records at the General Hospital, Calcutta, wrote, "Upon examining the records of medicine, from the earliest periods, it appears that physicians have never considered the living body subject, like all other parts of the universe, to regular and immutable laws" (Yates and Maclean, 1801, p. 13). Despite this refrain from bedside medicine, they used to perform regular autopsy at the hospital - "there was not one without confirmed local disease of the viscera, either of thorax or abdomen, or both” (Yates and Maclean, 1801, p. 54).

Like Paris hospitals and hospitals of London, white people dying at the hospital were mostly sailors and low and licentious Europeans in India (Fischer-Tine, 2009). They had little authority over their body. Poor Indian people took their recourse to the Native Hospital, Calcutta and other dispensaries. But, owing to cultural constraints and determinants, autopsies could not be initially done on Indian patients. Afterwards, such constraints eroded and there was an abundant supply of bodies for dissection to CMC. For example, from November 1846 to March 1847 only a span of 5 months - nearly 500 bodies were dissected by the native students in CMC. In Ruth Richardson's estimate bodies taken under the Anatomy Act (the first ten years from 1832-33 to
1841-42) for London hospitals only are 135, 141, 194, 206, 184, 209, 156, 168, 178 and 110 respectively, totaling 1,681 (Bhattacharya, 2011, pp. 63-108). Such a contrasting figure of 500 bodies dissected in six months at CMC against 1,681 bodies dissected in ten years at London hospitals made any alike of the Anatomy Act (1832) redundant in India.

Harrison notes that while in Britain the supply of bodies for dissection was still severely restricted, "there were no such constraints in the colonies, where cadavers were plentiful" (Harrison, 2010, p. 4). In his observation, "Modern medicine, or what was understood as such during the early nineteenth century, was as much a product of the colonies as of the infirmaries of revolutionary Paris; or, for that matter, of the hospitals and anatomy schools of Britain" (Harrison, 2010, p. 9).

Moreover, as argued by Trohler, medicine by the time needed demonstrations by “incontestable evidence”. Such a program demanded some organizational skills for producing and arranging "this new type of (group) data and for handing, them mathematically ... There were networks of doctors in eighteenthcentury Britain, chiefly army and navy surgeons and individuals working in new voluntary hospitals and dispensaries" (Trohler, 2005, pp. 2627). Such quantifying spirit was evident in all the books published by surgeons working in India. Hundreds of cases dying in military and naval hospitals were dissected and the results noted for future nosological, diagnostic and therapeutic purposes.

\section{To quote:}

On being appointed, soon after his arrival in India, to do duty in the Naval Hospital at Madras ... this practice (autopsy and its record) was regularly continued: Not, however, to the extent of a full case-book and perfect tables ... Regular entries were made of the principal cases only; and a 
general minute-book recorded the material circumstances in such as were of less importance. Full opportunity was enjoyed for dissections, and many were accordingly performed, and the appearances recorded at the moment.

(Charles Curtis, 1807, p. xviii).

Such "incontestable evidence" also gave birth to new medical facts suited to the tropical climate of India. This spirit was incorporated and assimilated in the new Indian institutions. To add, four important reasons were at work for constructing the background of case history. First, scientific spirit was the driving force for gathering new information and filtering them to put into practice. Second, it was a necessity of great importance to know the "other" climate and disease pattern from a higher civilizational podium. Third, to improve the deficit of the British Pharmacopoeia by recording new pharmacological properties of Indian plants (minerals too) through experiments on hospital cases. Fourth, in some cases, purely commercial interests also led to recording of medical cases.

Additionally, in Indian context, some changes heralded the beginning of hospital medicine in India - (1) the conceptual change in bodily image from two-dimensional to the threedimensional one, (2) the treatment of the patient in a hospital setting, not in his/her domestic environs, (3) touching and measuring the patient's body with the stethoscope, thermometer and other modes of inspection, and (4) the transition from the socially embedded person to case number in hospital, which perhaps led to a new type of “modern” identity.

Hospital medicine in India is inextricably intertwined with the establishment and development of the CMC. CMC etches out its significance in the history of medicine in India for many a reason. Quite importantly, it was instrumental in the production of individual case history of the patient, which was almost unknown before in Indian medical practices. The 18th-19th century case records were of European soldiers prepared and preserved by European doctors. Almost every surgeon had charge of 700 patients. They would keep a regular diary of cases (Transactions of the Medical and Physical Society of Calcutta, 1829, p. 171). In Harrison's argument, "Practitioners working in colonial hospitals" were "able to compare postmortem findings with the symptoms of disease in living patients, giving rise to a system of medicine not unlike that which later developed in revolutionary Paris" (Harrison, 2010, p. 4).

To note, though Harrison talks about surgical and pathological practices of the East India Company (EIC) surgeons, their practice did not automatically lead to the rise of "hospital medicine” in India. As I have argued so far, "hospital medicine" is a distinct phase in the evolution of modern medicine, which is clearly demarcated from the hospital itself though intimately related. This distinction is often overlooked and overlapped. Elsewhere, Harrison argues, "It is possible that the early history of hospitals beyond the West may shed some light on this and on the more general problem of what constitutes a modern hospital. If nothing else, it alerts us to the fact that modern hospital practices had multiple origins, some of which lay beyond Europe” (Harrison, 2009, p. 6). He questions, “Do we take as our starting point the new infirmaries of Enlightenment Europe and the advent of of the modern hospital in the institutions of revolutionary Paris, and the emergence of clinico-anatomical medicine?” (Harrison, 2009, p. 5). In this argument, the development and spread of hospitals are more weighed than the importance of "hospital medicine”.

"The advent of hospital medicine", following Jacyna's argument, "represented a move from this person-orientated to an object-orientated medical cosmology” (Jacyna, 2006, p. 56). Scholars have contended that Northwestern Europe and North America are the regions in 
which a certain kind of nation-state, with particular social and economic forms, medical organizations, and intellectual culture first generated the widespread view that science in medicine would benefit not only some individuals but all citizens (Cook, p. 2). Following these arguments, CMC was the receptacle where the medical training of native dressers and compounders at the NMI and other institutions, which came into operation for the twin need of military operations and economy of exchequer, metamorphosed into the new medical education through tools like hospital training, keeping case records, practical dissection, medical and surgical experiments and statistical analysis.

\section{Pre-CMC Case Records and Hospital Practice}

In $18^{\text {th }}$ century, Saunders found that "in India, the fever and dysentery, which are considered as the endemic of the country, have been found on dissection to be accompanied by diseases of the liver." Twining noticed, "The most remarkable circumstances connected with the dysentery of Bengal, are the extensive local inflammation of the mucous membrane of the great intestines, coeval with the commencement of the disease.” More precisely, “The patient dies. The body is permitted to be opened, and this it is supposed to explain everything." Curtis concluded, "Much experience indeed does it require; and many dissections of similar cases, to enable us to judge and distinguish accurately between the causes and effects of disease; and even between the effects of disease, and the effects of death” (Bhattacharya, Kumar and Basu (eds), 2013, p. 46).

But, to note, this sort of autopsy and pathological findings did not proceed further and were in no way related to other basic sciences. It is evident in the Curtis' statement, "Chemistry has not yet imitated, nor can it be supposed ever to imitate the operation by which chime is converted into completely animalized chyle ... We are pretty certain, that of all the secreted liquors, none are more susceptible of morbid alienation than the bile..." (Curtis, 1807, pp. 180-181). The big hand of humoral pathology with its thousand bonds is self-evident in this statement.

To rectify the error of applying European categories in Indian climate "to be met with in more than one communication on the subject of India diseases", Curtis informed, "is one of the object of the observations contained in the following sheets.” (Curtis, 1807, p. xx). It indicates that new types of cases, not observed in England, were of much curiosity to the surgeons of the EIC. More succinctly, he adds, "The classification and nomenclature of diseases, is a necessary measure to facilitate the study of them; but we ought always to keep in view, that the best nosology is in some measure an artificial, often a fanciful arrangement, and behoves of necessity to be always more or less to be local one” (Curtis, 1807, p. xix-xx).

In 1802, case records other than surgical ones began to be recorded. These may be seen as purely medical case records. These records were based on Jennerian vaccination data - "We have it now in our power to communicate the benefit of this important discovery to every part of India, perhaps to China and the whole eastern world" (Seton-Karr (ed), 1868, p. 329). On 2 July 1802, it was admitted with regret by William Moir and $\mathrm{H}$. Scott that even with this matter "we were for a time unsuccessful, and after thirty or forty trials by various methods and different Surgeons, a fortunate inoculation at length produced the vaccine disease in Anna Dusthill, who is perhaps the first human being who underwent it in India" (Seton-Karr (ed), 1868, p. 329-330). The production of case records through trials and errors were concimmitatnt with the introduction of Jennerian vaccine since its inception. Subjects chosen for the new vaccine would be received as out-patients at the Native Hospital on Tuesday and Friday mornings "where they will be inoculated 
with recent vaccine matter taken on the spot..." (Seton-Karr (ed), 1868, p. 565).

Besides the new vaccine, galvanism, as reported by Dinwiddie, was also a tool of medical or electro-chemical experiments in pre-CMC days - "Gavanism has, with me, been also successful in six cases of rheumatism, and three of palsy" (Seton-Karr (ed), 1868, p. 447).

In 1820, Peter Breton, the $2^{\text {nd }}$ superintendent of the NMI, made some crude experiments with the bark Swietenia febrifuga. He put this drug on trial "in a number of cases of confirmed remittent bilious fevers” (Breton, 1821, p. 312) With an un-opposed field of chemical experiments consisting of poor sepoys and other half-caste people, even crude experimenters like Breton doing experiments at a very rudimentary level did not miss any opportunity to put new vegetables and drugs on trial - "I have also put this drug to the test of trial in three cases of gangrene and mortification, and in a case of suppurated liver” (Breton, 1821, p. 312).

His uncertainty about the efficacy of European therapeutics also becomes visible - "In medicine, more than in any other branch of philosophy, it is extremely difficult to unfold, with precision, the causes which operate in producing alterations, either in healthy or morbid bodies, and I am well aware, that effects are often ascribed to medicine which belong exclusively to nature" (Breton, 1821, p. 313). To uphold Breton's efforts, James Johnson noted, "From dissection, the colon seems to be primarily affected; and the bladder suffers only from communication, as the lower part of the large intestines is generally inflamed ..." (Johnson, 1824, p. 303).

One can very well realize an intriguing trajectory of the production of case records - from indigenous herbs to vaccine, from galvanism to autopsy, from medical cases to surgicopathological ones.
We should note that all these case histories were kept by European surgeons and, primarily for European patients. Things began to change, especially following some important happenings - first, the introduction of the stethoscope in Indian practice, and second, the foundation of the NMI in Calcutta (Alavi, Islam and Healing, 2007), medical classes at the Sanskrit College in Calcutta, and, subsequently, a small hospital attached to it and, also, the School for Native Doctors in Bombay.

W. E. E. Conwell, a staff surgeon of the East India Company, Madras, was possibly the first person to submit the cases he studied and his notes on the stethoscope to the judgments of his colleagues in India in 1827 (Conwell, 1829).

At the NMI the medium of instruction of native students was vernacular. Some of the new diagnostic techniques like thermometer and auscultation became popular among the Company's surgeons and Indian doctors. The NMI students had their hospital exposure and clinical rounds at different hospitals and dispensaries in Calcutta. For the first time in Indian context they began to take case histories of individual patients. They used to examine "bringing the ear close to the mouth or chest (auscultation) of the patient, or on applying the hand over the latter (palpation), as recommended for percussion.” (Adam, 1828, p. 324).

As an aside, reflecting uncertainty of European medicine vis-à-vis epidemic disease in India, one evidence of treatment of the epidemic cholera by a Unani physician was reported in a letter (May 1, 1818) to the editor of the Asiatic Journal - "Having observed in the Calcutta newspapers, for some time, various modes of treating the pervading epidemic, cholera morbus ... the treatment observed by a Mogul physician, to the spontaneous of which I have been an eyewitness of my own house, in more than one instance; and particularly when I was myself attacked with it...” (Treatment of the Epidemic 
by Moughal Physician, 6, 35(1818): 474). It is important to note that what was an event for the "Mogul physician" became a case through this reporting. An event was transformed into the case through scientific and literary trope as well as a particular mind-set consistent with the rising political and state ideology of the time.

In Bombay too, the Medical Board directed "regular returns to be kept of all patients who may be operated on, distinctly specifying the state of each prior to operation, and the result or degree of benefit that has been obtained by each..." (Asiatic Journal, 1824, p. 400).

The brief phase of the NMI and medical classes at the Calcutta Sanskrit College can be regarded as the period of the gestation of hospital medicine. It was important in another aspect. “The pupils of the Native Medical Institution ... keep a case-book of the symptoms and treatment of the sick on the establishment” (Williams, 1859, p. 56). I would emphasize that the NMI phase may be better understood as the phase of visual, verbal and psychological acculturations with the new medicine. It started with exposure to human bones, anatomical plates, and observing patients in various states of diseases in different hospitals and dispensaries.

Taking a cue from Gelfand (Gelfand, 1981), CMC was not a phenomenon of any sudden emergence. The new medical epistemology had its "gestation period" and nativity. By virtue of their training in a medical institution (NMI), the students became doctors, as perceived by the population at large. Along with their primary training in surgery, as noted above, they were also inducted into basic sciences like rudimentary chemistry, material medica and pharmacopoeias (Jaggi, 2011, p. 42). The NMI systematised medical instruction and laid out strict codes of medical apprenticeship and training (Alavi, 2007, p. 75). Pre-CMC training also foregrounded the absolute necessity of hospital of some kind for proper medical teaching (Sen, 1991, p. 147). All these taken together were in need of an institution of a new genre. The "gestation period" ushered in the era of hospital medicine and a new kind of medical cosmology and education in India.

During their 3-year course at the NMI, they learnt the "names, doses, and properties of the medicine they employed, and the more intelligent could point out the treatment of some common diseases ... and the habits of attention and observation they had acquired rendered them greatly preferable to former class of Native Doctors who were destitute of these advantages" (Sen, 1991, p. 139). For better visual acculturation, John Tytler, the then superintendent of the NMI, after a preliminary lecture, began with bones and "as usual with the head go regularly through the whole, pointing out their processes and foramina, the attachment of muscles and the passage of vessels and nerves" (Sen, 1991, p. 139).

Tytler's trope of visual and psychological acculturation attained such a crescendo that Durshun Lall, a Hindu pupil, brought him a skull his friend had picked up in the banks of the Ganges (Sen, 1991, p. 142). The anatomical learning was regarded as a universal referent and social leveller. According to Tytler, "Before the knife of the anatomist every artificial distinction of society disappears...” (Tytler, 1830, p. 14). Modern anatomical knowledge began to reconstitute the psyche of the new entrants who would learn about a human body with "necessary inhumanity" and clinical detachment. The body became an object, not an embodied entity.

What the NMI actually lacked were - (1) there was only zootomy, not actual dissection; (2) no well-defined curriculum and well-organized staff; and, importantly, (3) the conduits of internalization of Western medicine in its entirety. Regarding CMC, an official report clearly stated, "The institution differs from that of Dr. Tytler, in as much as the subjects are taught practically, by 
the aid of the Dissecting Room, Laboratory, and Hospital" (Report of the General Committee of Public Instruction ... for the Year 1839-40, p. 34).

A few plates which were shown and taught to the students of the NMI, Sanskrit College, Calcutta, and the School for Native Doctors, Bombay, may be exemplary here to show how visual acculturation took place.

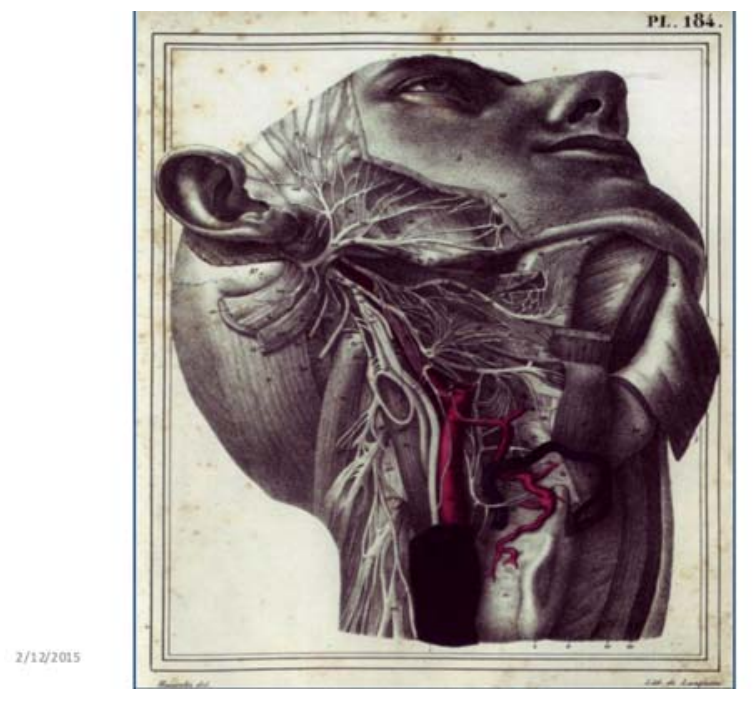

Cloquet's Anatomical Plates

These figures were adopted unhesitatingly from English textbooks and reproduced replacing the English terms with Bengali or Sanskrit. An illustration from an Āyurvedic text is shown

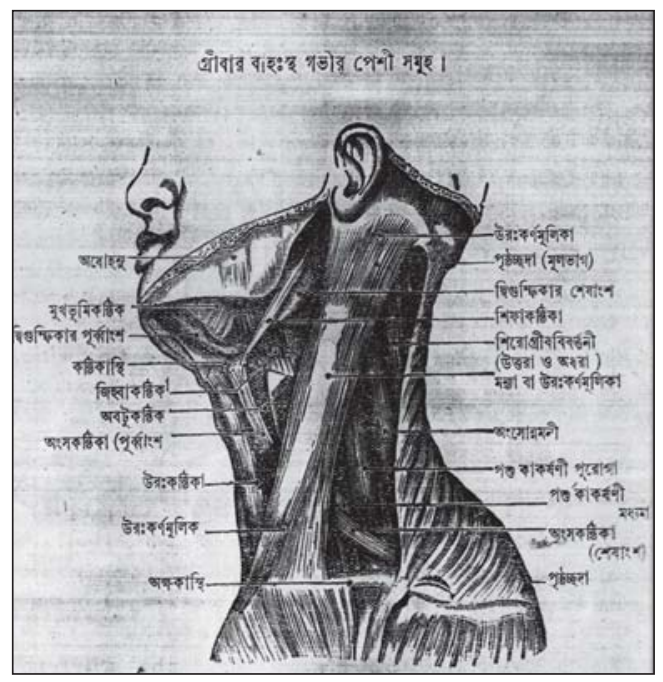

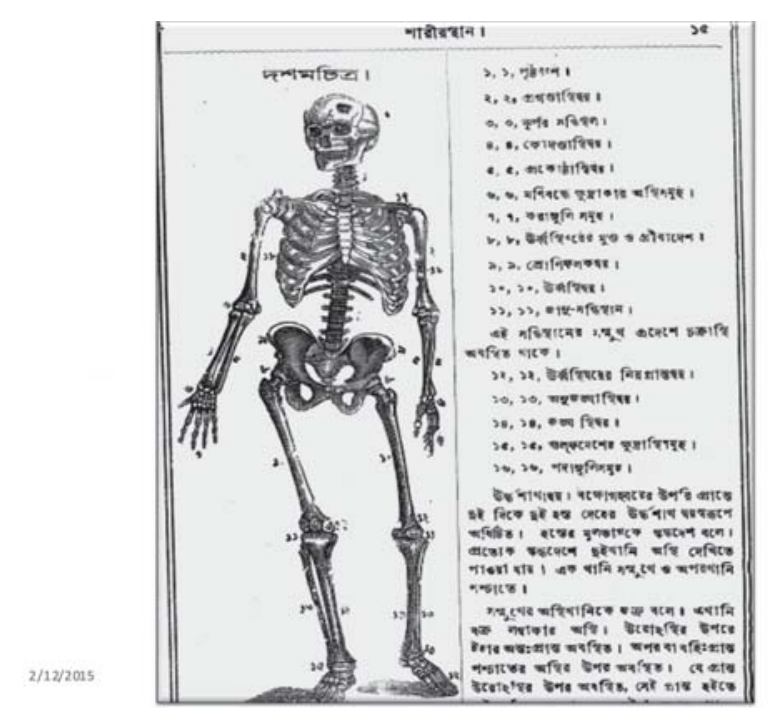

below. This was basically an unabashed act of mimicry.

\section{CMC - Case Records and The Rise of Hospital Medicine}

CMC etches out its significance in the history of medicine in India for many a reason. It is the first medical college not only in India, but also in Asia. Even when in England, the separation between the physician and the surgeon existed it was resolved in the training of the CMC (Goodeve, 1836, pp. 19-26).It is the first institution outside England to be recognized by the Royal College of Surgeons of England, the University of London and the Society of Apothecaries of England (1846). It produced trained physicians and surgeons combined in one person who extended the application of modern medicine not only throughout India, but also a part of South and South-East Asia (namely, Sri Lanka, Singapore and Myanmar). It took up various experiments, especially the chemical ones. Ether and chloroform were introduced for the first time in India. These were the first instances of such experiments beyond the Euro-American borders. Four of the students of the CMC making their voyage to England overcame "the actual dangers of war superadded to the dread of the sea, so firmly implanted in the mind of every Hindu.” It showed 
in a conclusive manner that Indians could master science and medicine on a level with Europeans (Gorman, 1988, pp. 276-298). Finally, CMC was the receptacle where the new tools of medicine like the stethoscope, microscope, hospital training, keeping of case records, practical dissection, and medical and surgical experiments were successfully introduced.

To mention, unlike Ayurveda, in Unani medical practice, there was custom of keeping case records of patients by name (Alavi, Islam and Healing, 2007). But it was fundamentally different from the new medicine with regard to anatomical dissection and organ localization of disease.

In Indian perspective, the British were in need of (a) the internalization of Western medicine by Indians, and (b) the production of generations of students to perpetuate the mechanism through the new collegiate system introduced in 1835 . The CMC became successful to perform both the ambitious tasks through successful operations of the three modes of acculturation processes visual, verbal and psychological.

CMC introduced "the timid Hindoo youth to the use of scalpel, without offending the delicate nerves and still more delicate conscience too sensitively" (Native Medical Institutions, Asiatic Journal and Monthly Register, 1835, p. 226). Through all these maneuvers, it became the first institution in India to give birth to hospital medicine.

Modern medical teaching based on hospital training later developed in Madras and Bombay in quick succession. "A medical school was established at Madras by G. O. of $13^{\text {th }}$ Feb., 1835 ... classes began in July 1835” (Crawford, 1914, p. 446). In Bombay, a “dispensary or hospital was established in 1834, but there was no school or institution of any kind for providing medical education along western lines” (Sen, 1991, p. 231). Finally, in 1845, Grant Medical College was established.
Briefly speaking, the Committee appointed by Lord Bentinck in Calcutta submitted their report on October 1834. They summarized the defects of the NMI. Some of which were - (1) the absence of proper qualifying standard of admission; (2) scantiness of means of tuition; (3) the entire omission of practical human anatomy in the course of instruction; (4) the shortness of the period of study; (5) the want of means and appliances for the convenience of private study; etc (Crawford, 1914, p. 435). The $31^{\text {st }}$ clause of the G.O. of January 28, 1935 emphasized the importance hospital and dispensary visits.

Another important contribution of the new hospital was its secular nature. "Within the walls of the hospital the rules of caste in which the whole system of native life is swathed, as in mummy bandages, are suspended" (British Medicine in India, May 25, 1907, pp. 1245-1253).

\section{Division of Case Records}

For better understanding, case records may be divided into different orders and categories. To note here that there existed a division between European and Indian patients. A great disparity was visible in the allocation of diet in hospital too. The daily charge for "the diet of each patient shall be for Europeans four annas, and for Natives one anna" (Rules and Regulations of the Bengal Medical College, 1849, p. 40). Again, while medical cases were treated at the General Hospital, Calcutta, surgical cases were treated at the Native Hospital, Calcutta, and other dispensaries (Macpherson, 1841, pp. 546-551).

However, it was explicitly stated, "On the admission of a patient into hospital he shall be sent to bed, his clothes shall be removed, and taken care of, and he shall have a hospital dress of clean linen put on ... The disease shall be noted on a ticket with the diet, date of admission, \&c" (Rules and Regulations of the Bengal Medical College, 1844, p. 30). Interestingly, a person in his domestic 
setting was made an object of hospital with a particular number. His subjectivity was erased to produce a new numerical identity. "All cases shall be stitched in a book, and the number of each case shall correspond with that of the preparation" (Rules and Regulations of the Bengal Medical College, 1844, p. 41). And these were grouped together to produce statistics where a person became nameless and faceless object - "A general register of all the cases admitted into hospital shall be kept, and available for statistical purposes" (Rules and Regulations of the Bengal Medical College, 1844, p. 32).

Another way of viewing at the case records may be grouping the cases related to different kinds of experimentations done - medical, surgical and chemical. In Indian context, the division between hospital and laboratory medicine - as suggested by Pickstone - seems to merge together.

With the establishment, growth and development of dispensaries some additional new features were attributed to the case records. Unlike case records kept by individuals like Curtis or Breton, they gradually became institutionalized.

Moreover, almost all the dispensaries throughout India and neighboring countries were run by graduates from the CMC. Ram Narrain Doss (a graduate from the CMC) reported, "I have operated for stone on twelve subjects, and am proud to say that I have been successful in all of them, all got well ... four cases of lithotomy have been operated...” (Sykes, 1847, p. 7). Through the act of recording cases and using them for future statistical records, a new bent of mind and vision - mathematical and statistical mode of thinking were germinating among the new graduates. It led to, as I argue, more objectification of the person of the patient. The personhood of the patient was reconstituted into numerical figures which could be used for future medical purposes and in the interest of the state.

Third, since public health took its real shape with the expansion of the dispensaries, the population at large was instilled with an adequate understanding of the principles governing health and sickness. "Medicine thus acquired a political status inasmuch it has gained a new relevance to the interests of the state” (Jacyna, 2006, p. 82).

In a similar way, the Indian body became subservient to the political code of the state on the one hand, and objectification on the other hand. Allan Webb, in his introductory lecture to the students of CMC, emphasized, "India presents before you a fine field of observation” (Allan Webb, 1850, p. 34).

These statistical reports, though not always following rigorous statistical norms and methods, also provided "information regarding the superstitions, the prejudices, the customs and manners of the natives” (Sykes, 1847, p. 9).

\subsection{Medical Case Records}

In 1837, David Hare wrote to J. C. C. Sutherland, "the well regulated supply of patients should be submitted to their (students) charge for the express purpose of illustrating their lectures. And that the most ample opportunities of witnessing disease in every variety should at the same time be furnished to the pupils" (Report of the General Committee of Public Instruction of the Presidency of Fort William in Bengal for the Year 1836, p. 164). Here also, as Hare's letter makes it evident, it had to pass through a phase of ocular and psychological acculturations. Hospital training, in Hare's words, was “a very great advantage in this country where many of the diseases are so rapid as to require constant watching by those who wish to study them with profit, or who desire to benefit the patients under their charge" (Report of the General Committee of Public Instruction of the Presidency of Fort William in Bengal for the Year 1836, pp. 164-165).

Prior to the period of internalization of Western medicine through so many tentacles of institutionalization and other tropes, innumerable case records were produced in various hospitals 
in Calcutta. The following figure should clarify it (Appendix I. To Second Report of Committeee upon the Fever Hospital and Municipal Improvements, 1848, p. 278).
To become a case in a hospital ward was quite intimidating in Indian perception, "if once the idea gets abroad into the minds of the Native population, that the Hospital is a part of the college

278

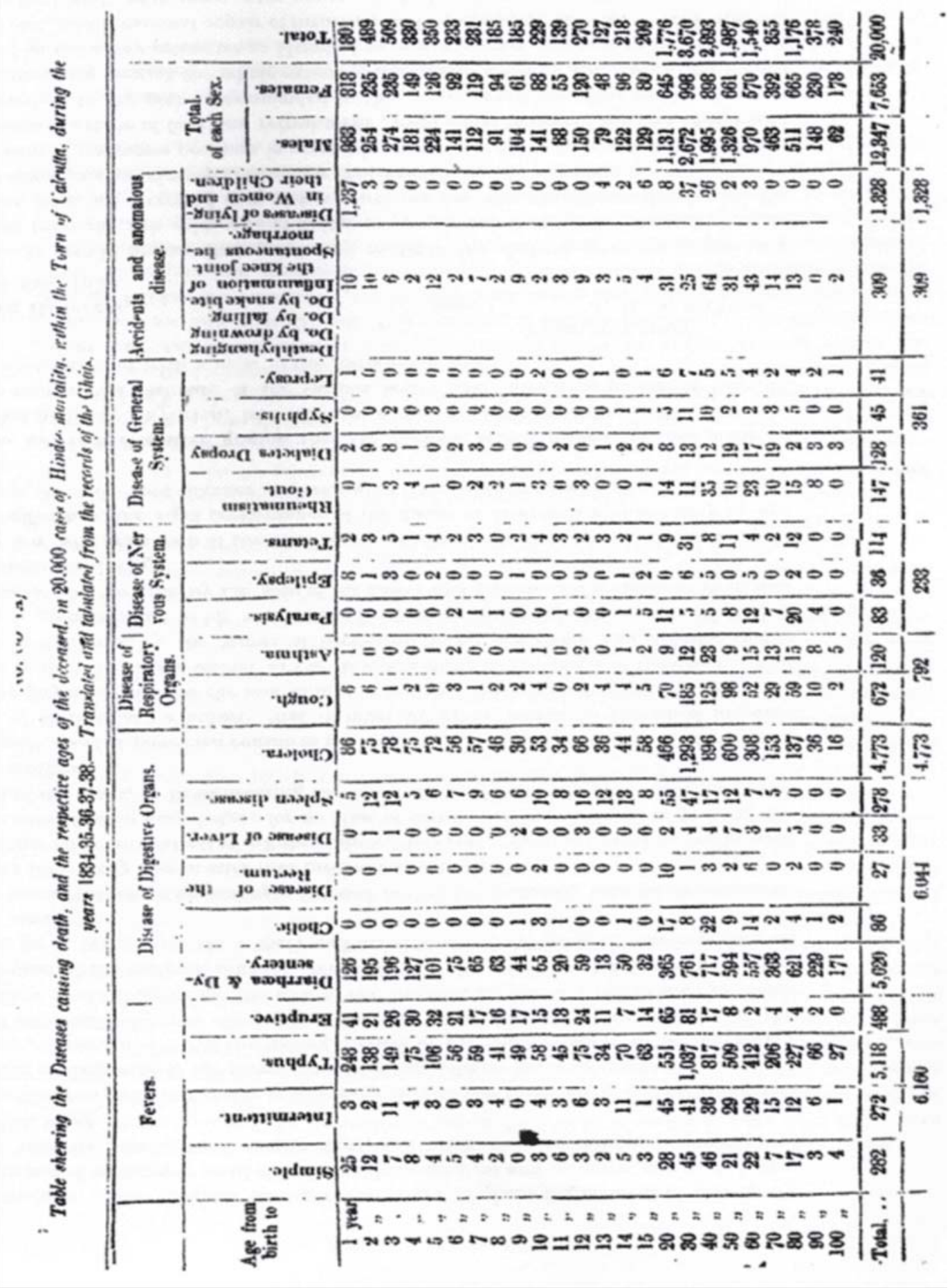


establishment, and the source from whence subjects for dissection are to be supplied to it, its usefulness for the purposes of General Hospital of relief to sick Natives is at an end" (Appendix C. Evidence Taken by the First Sub-Committee upon the Fever Hospital and Municipal Improvements, 1838, p. clvi).

It is somewhat similar to popular perception of dissection in early $19^{\text {th }}$-century England. Unfortunately, the colonized and hapless scared people could not react in a pro-active way as was in England. In England, reacting against dissection of bodies buried in the grave "the poor instead clubbed together to provide protection in the event of a death" (Richardson, 2000, p. 83).

In both the cases, going against the modern medical trend, poor people wished to remain a person, not a conglomerate of dissected organs or a case number in a hospital.

The new emerging medicine in India comprised case history of individual patients, administering drugs and diet appropriate to them, examining therapeutic results thereupon and, finally, corroboration of symptoms of a living patient with pathological findings with the aid of autopsy when he is dead. Additionally, instead of writing a prescription in full, the CMC students were often taught how to indicate only formula to be employed later to save time (Calcutta Review, January-June 1843, p. xviii). In Indian context, case history per se made its journey from the ship's surgeon's case books and European hospitals to an altogether different kind of case history compatible with the new kind of medicine.

Jaudub Chunder Dhara, a sub-assistant surgeon of the Allahabad dispensary, noted, "the happy and wonderful effects of the nitrate of silver, in a species of skin disease very common in India ... The Hakeems have no cure for it, and I believe the disease not known in Europe" (Sykes, 1847, p. 17). His dispensary patients were cases for therapeutic trials.
The internalization of Western medicine found its full expression, as I find, in Soorjo Goodeve Chuckerbutty. He was a pioneering experimenter at CMC. Following Martin and others' clinical trials with iodine in a hospital setting, Chuckerbutty published his paper on "Iodide of Potassium in the treatment of Aneurism” (Chuckerbutty, 1862, p. 85-86). He treated a number of patients of CMC with potassium iodide in his own way. He performed autopsy in all these cases to corroborate symptoms in the living patients with pathological changes in the dead body. He took careful case history of each of them and applied it on three European patients in the CMC.

Notably, iodide was principally tried in hollow organs like the scrotum or an arterial aneurysm or in cases of bronchocele or thyroid gland.

Importantly, Chuckerbutty preceded British trials in this regard. His trial was published in July 1862, while similar British trial was published in January 1863 (Roberts, 24 January 1863, pp. 83-85). He reported about amyloid degeneration which was microscopically confirmed by his colleague Kanai Lal Dey (Chuckerbutty, 1863, pp. 680-81).

In the case of an epilepsy Chuckerbutty tried ice with remarkable improvement. He reported, "I only hope that my professional brethren will see from the perusal of this case the reasonableness of applying ice in similar instances” (Chuckerbutty, 1852, p. 408).

It may be profitable here to take a glimpse of the interrelationship between American ice trade and medicine in Calcutta in the late 1830s. Frederic Tudor, the first major ice entrepreneur, failed to dominate the global coffee market. "He inaugurated his India venture only after experiencing a desperate need for adequate cash flows and profits in order to repay enormous debts incurred through his misadventures in coffee ... 
although Calcutta was to become Tudor's most profitable market, it became so largely because the East India Company (and later, British Indian) authorities made it so profitable by special exemptions” (Dickason, 1991, 53-89, p. 55). One hundred tons of Tudor's ice was unloaded at his ice-house in Calcutta in September 1833 (Herold, 2011, p. 165). Frederic Tudor wrote a letter to the editor of the Calcutta Monthly Journal emphasizing the importance of importing ice (American Ice, 1837, pp. 118-119).

Most interestingly, the American ice, which used to be carried from the Pennsylvania ports to Calcutta only to make the ship heavier, was projected as an excellent medical therapy for various diseases. 22 doctors of Calcutta (including those serving at the CMC) wrote letters for its promotion among the medical community (Calcutta Monthly Journal, 1838, pp. 270-275). They strongly recommended ice for the alleviation of various diseases unique to tropical climate. Most eminent figures like J. Grant, H. H. Goodeve, A. R. Jackson, W. B. O'Shaughnessy wrote in favor of ice. For W. B. O’Shaughnessy, “the successful importation of ice, and its constatnt preservation in Calcutta, place within the reach of the humblest member of the community, a remedy of the highest efficacy in the treatment of many varieties of tropical disease" (Calcutta Monthly Journal, 1838, p 270-275). J. R. Martin observed, "ice is of the highest utility in the ordinary gastric (commonly called bilious) remittent fever of Bengal” (Calcutta Monthly Journal, 1838, p. 272). Brett tersely commented, "I am of opinion that ice is most valuable in certain cases of mania, in fever where the brain is affected in hemorrhage, and, especially, in cases of uterine hemorrhage (bleeding) in strangulated hernia, \&c" (Calcutta Monthly Journal, 1838, p. 273). All these noted surgeons and physicians of Calcutta provided a new kind of case records under the influence of new commercial activities.
In an age of new scientific experiments and keeping case records of these experiments, it may be presumed that the effect of ice on all these cases were kept. Patients were relocated within a nexus of commerce-medicine-state, dislocating the prevailing religious, societal and community interconnectedness of Indian medicine. The commerce-medicine-state paradigm became the new "religion” of scientific medicine. Evidently, commerce played its visible role in clinical trials and, obviously enough, in the production of case history. In another context, Chakrabarti addresses somewhat similar question - "This unique concoction of trade, piety and culture added its essence to the medicinal herbs of the Coromandel” (Chakrabarti, 2010, p. 135).

Again, coming back to Chuckerbutty, he strongly advocated for compulsory registration of the medical graduates. 'Every druggist and chemist, every apothecary and quack, every sluggard, fool, and rogue, enjoys as yet full liberty to style himself a doctor and prescribe for the sick' (Chuckerbutty, 1864, p. 111). In 1864, he enumerated 29 types of different medical practices prevalent in Calcutta alone (Chuckerbutty, 1864, p. 111).

Chuckerbutty was the first covenanted Indian surgeon of the IMS. Interestingly, He unhesitatingly likened the European medical officers to "only bird of passage" and, as a result, "could not, therefore, permanently improve the position and prospects of the profession out of the service” (Chuckerbutty, 1864, p. 88). In a move to replace these birds of passages, internalization of modern medicine was imperative. Chuckerbutty was the person with this mettle.

Mohendralal Sarkar, the founder of the Indian Association of the Cultivation of Science as well as a later homeopathic practitioner of Indian type, published his paper on hepatic abscess in the British Medical Journal (Sarkar, 1854, pp. 36-37). 
Earlier, in the Rules and Regulations of the Bengal Medical College, it was clearly stated, “A general register of all the cases admitted into hospital shall be kept, and available for statistical purposes” (Rules and Regulations of the Bengal Medical College, 1844, p. 32). It is understandable that hospital cases were not simply cases in their own right. They were later used in the production of new statistical figures of disease pattern and, also, for preservation at museum after death.

Another example of keeping case records from a different medical perception was that from Balfour. He wrote a full length book on solar and lunar influence on fevers. Though, to mention, his endeavor was not adopted as a general practice. Balfour observed, "The disorders were chiefly fevers, or fluxes attended with fever; and in the space of the first month above 400 men were taken ill. The greatest part of these however got quit of the fever in the course of the eight days which intervened between the full and change, and, by the assistance of medicine were soon reduced to 70 or 80 ” (Balfour, 1815, p. 31).

W. B. O’Shaughnessy was possibly the first person in India to steer medico-chemical experiments on animals. From his report of 5 October 1835 (after the foundation of CMC), we come to know that Mr. Foy of the General Hospital, Calcutta, had administered one drachm of Nux vomica extract to two dogs. "The dog to which was administered one drachm of the extract was first convulsed one hour and twelve minutes after, and after a few rapid and strong fits convulsion died one hour and thirty one minutes” (Caution to the Public: Nux Vomica Bark sold in the bazaars, as the Rohun, or Swietenia Febrifuga, 1837, p. 288) The editor of the journal noted, "With the view of making ourselves acquainted with the foregoing important subject, we attended at the College (CMC), and Dr. O’Shaughnessy, in our presence, again performed the experiment to which he has alluded" (Caution to the Public: Nux
Vomica Bark sold in the bazaars, as the Rohun, or Swietenia Febrifuga, 1837, p. 288).

Of so many indigenous drugs being tried at those early moments of institutional fortification of medical knolwdge through case records, one was "Substitute for Jalap" - the seeds of Ipomea carulea (sic). It was "extensively tried in the Native and Police Hospitals of Calcutta, and has been in every case found superior to jalap" (Watt, 1840, p. 156).

\subsection{Surgical Case Records}

Surgical case records are notable for two purposes. First, these records came out of purely surgical practices. Second, unlike England, these surgical practices, undeterred by any professional body or state regulations, were later applied in Europe too.

R. O'Shaughnessy tried his new method of removal of large jaw tumours in the CMC (O’Shaughnessy 1857, pp. 138-142). More than 30 cases were operated on. These records widely gained attention and recognition as supported by their publication in international journals. Indian experience and experiments were merging with international academia and gaining a universal character.

In the annual report of the CMC for the session 1847-48, there is mention of surgical operations done by both Indian students and European professors. In total, 320 cases were operated on, out of which 296 were cured and 24 died. There were major surgeries like amputation, removal of tumours, lithotomy (General Report on Public Instruction (henceforth GRPI), 1848, pp. 77-118). All these cases were inclusive all races and caste - Brahmin, Hindu, Mohammedan, Christian and other low-caste people. Most surely, hospital medicine imparted secularity on medicine as an ontological question. 
For better understanding, some of the case records may be subgrouped under anaesthetic and obstetric case records.

Duncan Stewart reported, "I must not omit to mention in this place the successful introduction into our practice of the new anaesthetic agents, ether and chloroform; the latter of which was employed in two cases of operative procedure with perfect safety and success in the presence of several the professors and a number of the students” (GRPI, 1848, Appendix E. No. VII, p. cli). Among the prominent points of interest referred to "were the extraordinary success of some of the graduates of the College in the performance of the formidable operation of lithotomy, and the valuable results which had followed the introduction of chloroform into the practice of surgery" (GRPI, 1851, p. 122).

Stewart mentioned in his report about the successful introduction "of the new anaesthetic agents, ether and chloroform; the latter of which was employed in two cases of operative procedure with perfect safety and success in the presence of several of the professors, and a number of the students" (GRPI, 1848, Appendix E. No. VII, p. cli). This report was sent for publication in the Register of Indian Medical Science.

One evidence of Indian rhinoplasty may be mentioned here. Cowasjee's nose (a deserter from Tipu Sultan's army) was reconstructed by a “tile-maker” family of Poona. It was first reported in the Madras Gazette in 1793, and, finally, reported by Barack Longmate (BL) in the Gentleman's Magzine in 1794. It paved the way for new endeavor in rhinoplasty in Europe, especially by Carpue (Van de Graaf, 2009, p. 226). The important thing to note here is performing rhinoplasty or nose reconstruction was an event for the "tile-maker" family of Poona. It turned out to be a case when reported by Longmate.

Figures and the letter from the Gentleman's Magazine are reproduced below.
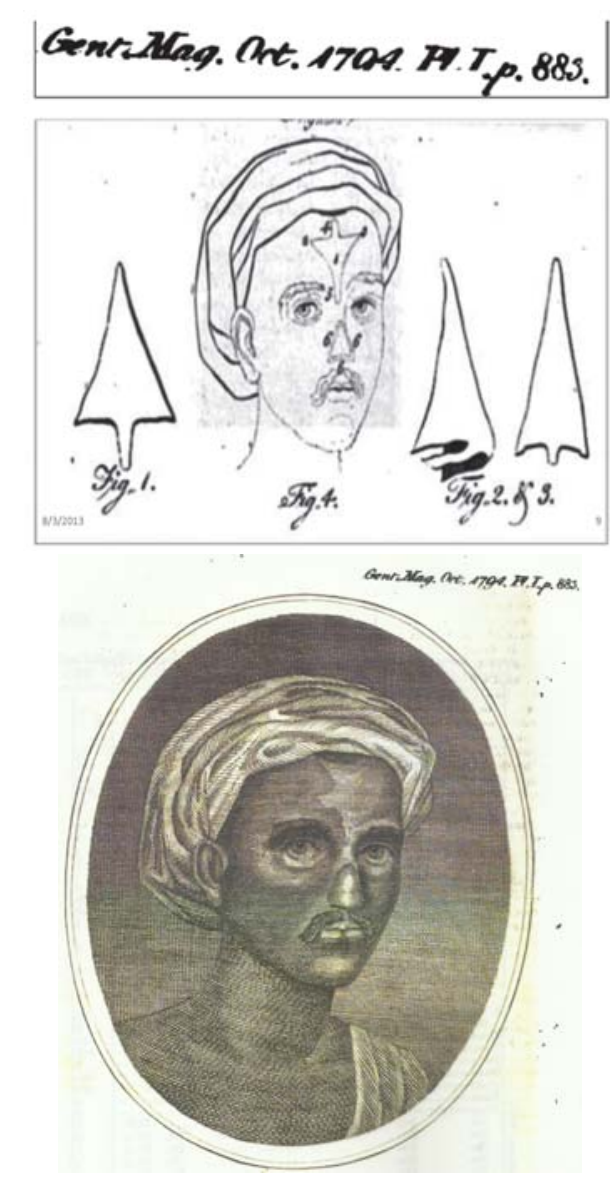

Mr. URBAN,

O.7. 9. A FRIEND' has trahtmitted to me, A. from the Eaft Indies, the follow: ing very corious, and, in Europe, I believe, urknown chirurgical operation, which has fong been practifed in India with fuccefs : namely, afixing a new nofe on a man's face. The perfon reprefented in plale $\boldsymbol{t}$. is now in Bombsy.

Cowesjex, a Malirsta of the caft of hufbandman, was a bullock-driver with the Engiih army in the war of 1792, and was made a prifoner by Tippoo, who cut off his nofe and one of his hands. In this ftate he joined the Bombay armv near Seringapatam, and is now a penfioner of the Honourable Eaft India Company. For above 12 months he remained without a nofe, when he had a new one put on by a man of the Brickmaker caft, near Poonah. This operation is not uncommon in India, and has been practifed from time immemorisl: Two of the medical 
gentlemen, Mr. Thomas Crufo and Mr. James Trindlay, of the Bombay prefidency, have feen it performed, as follows: $A$ thin plate of wax is fitted to the ftump of the nofe, fo as to make a nofe of a good appearance. It is then flattened, and laid on the forehead. A line is drawn round the wax, and the operator then d-ffects off as much ikin as it covered, leaving undivided a fmail flip between the eyes. This flip preferves the circuiation till an union has taken place between the nesv and old parts. The cicatrix of the ftump of the nofe is next pared off, and immediately-behied this raw part an incifion is made through the fkin, which paffes around both ale, and goes along the upper lip. The $\mathrm{k}$ in is now brought down from the foreluead, and, being twifted half sound, its edge is inferted into this incifion, fo that a nofe is formed with a divuble hold above, and with its ale and fepeum below fixed in the incifion. A-little Terra Japonica is foftened with water, and being fpread on Alips of cloth, five or fix of thefe are placed over eath other, to fecure the joining. No other dreffing but this cement is ufed for four days. It is then removed, and cloths dipped in phee (a kind of butzer) are applied. The conneEting flips of $\mathrm{Kkin}$ are divided about the $25^{\text {th }}$ day, when a little more diffection is ncceffary to improve the appearance of the new nofe. For five or fix days after the operation, the patient is made to lie on his back; and, on the tcnith 1794.] Defription of Wetton,-Curious Cbirurgical Oparation. 891

tenth day, bits of foft cloth are put into the noftrils, to keep them fufficientiy open. This operation is very generally fuccefsful. The artificial nofe is fecure, and looks nearly as well as the natural one; nor is the fear on the forehead very obfervable after a lengih of time. The picture from which this engraving is made was painted in January, 1794, ten months after the operation.

\section{Fig. x. the plate of wax when flat- tened. \\ Fig. 2. and 3. the plate of wax in the form of the nole.}

Fig. 4. 1. figure of the fkin taken from the forehead; 2 . and 3 . form of the ala of the new nofe: 4. Joptam of the new nofe; 5 . the flip left undivided; 6. 6.6. the incifion into which the edge of the fkin is ingrafted.

$$
\text { Yours, \&c. }
$$

Umachurn Set, sub-asistant surgeon of the Agra dispensary, reported, "the surgical diseases predominate vastly over the medical ones, a circumstance proving clearly the greater confidence they place in our treatment of the former than that of the latter ones ... Hakeems failed in curing or affording relief sought for" (Sykes, 1847, p. 18).

One of the recurring themes in the reports provided by Indian sub-assistant surgeons is the utter inefficacy of the indigenous mode of treatment. Also, to note, "The sick poor, however, seem to place an unbounded confidence in our treatment of both medical and surgical diseases ... partly to their being unable to purchase the native medicines from the Hakems, partly to their being much less influenced by religious prejudices, which exercise so powerful a tone of authority over the thoughts and actions of the higher classes..." (Sykes, 1847, p. 19).

The Calcutta Hospital was an exception for being without any dispensary attached to it. It relieved "annually an amazing amount of suffering” (Sykes, 1847, p. 21). In 1842, 294,885 patients were relieved, while, in 1843, the figure stood at 307,112. Most of these patients were indigent and poor sick. Unlike rich and elite people, they had no other choice than being registered as cases at the hospitals or government dispensaries. Actually, such a vast mass of the population made the hegermonic victory of Western medicine possible in India. They became 
the space for exploration into innumerable medical and surgical experiments.

The new epistemology of modern medicine derived its sustenance from both the elite group of people and the poor people who were actual beneficiaries (as well as guinea pigs) of modern medicine. With the passage of time, when European medicine became institutionalized thorough the CMC as well as it became the hallmark of modernity, more authoritative surgical case records were provided by F. H. Brett, surgeon of the CMC, in 1840 (Brett, 1840).

NOTES.

50]

Annual Report of Surgical and Medical diseases in the Central Hospital an Hospital of Surgery, from $17 t h$ December, 1836, to $281 \mathrm{~h}$ December, 1887.

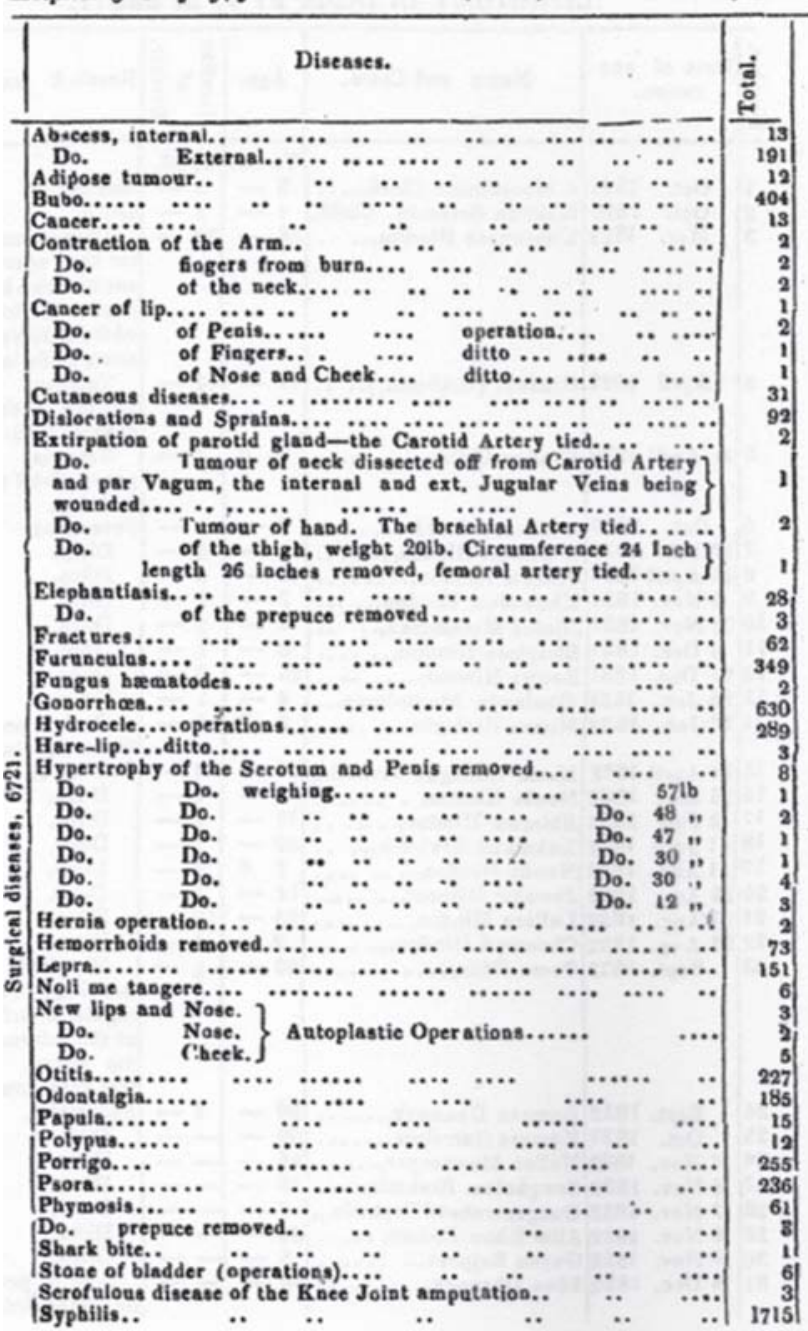

In later period, Raleigh's return shows the number surgical cases (Third Report of the Committee Appointed by the Right Honourable Governor of Bengal for the Establismnet of A Fever Hospital, 1847, pp. 63-68).

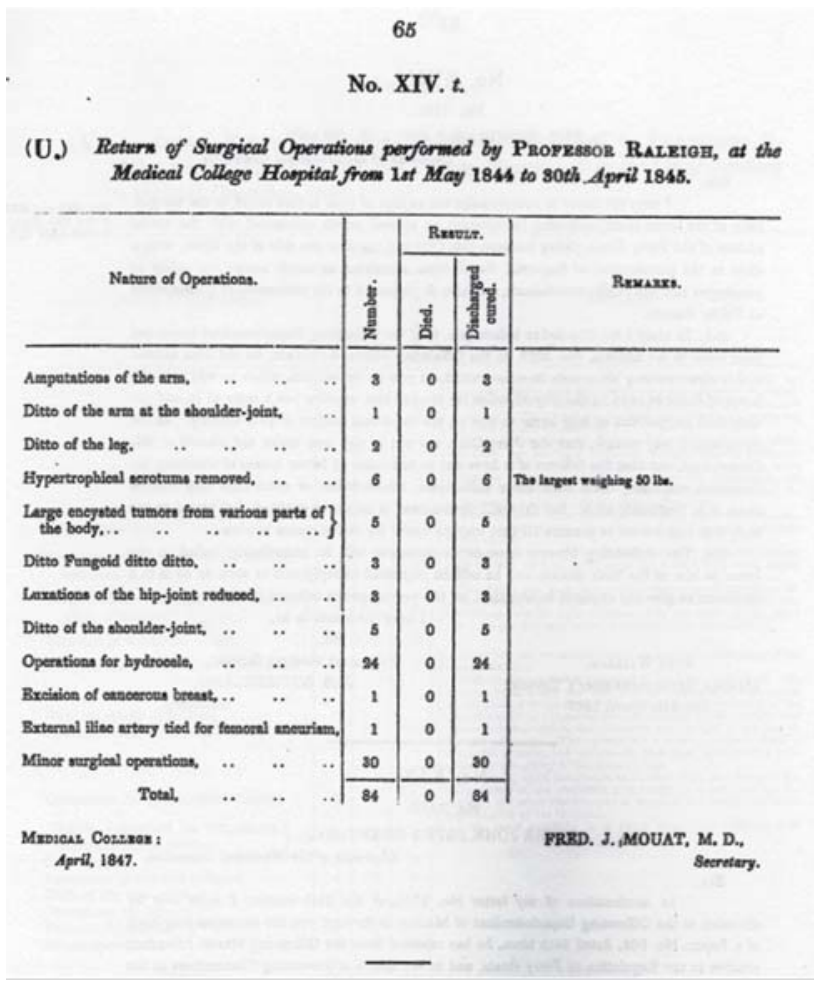

\subsection{Chemical Case Records}

In 1810, Fleming contended that Swietenia febrifuga, as proven by Roxburgh, contains a considerable tonic power and proved a useful remedy for the intermittent fever. Fleming noted, "he (Roxburgh) made trial of it in several cases of that disease, and found it fully to answer his expectations. With the view of further investigation, he afterwards, sent a quantity of the bark to England, where it was tried in hospitals, with equal success, and considered a valuable substitute in many cases, for the Cinchona" (Fleming, 1810, p. 39). New chemical substances began to be tried in vivo on Indian subjects. These people were mostly the meek and docile recipient.

In the late 1830s, W. B. O’Shaughnessy made extensive experiments with his newly 
discovered drug narcotine, supposed to be a substitute of quinine, on patients in the CMC (O’Shaughnessy, 1839, pp. 606-607). As we have seen earlier in case of "American ice", this particular trial with narcotine also came out of a specific historical situation of global commerce and war. As "Peruvian Government had suspended the exportation of cinchona bark for a period of five years", an inquisitive mind of W.B. O'Shaughnessy had no other choice than discovering a substitute of cinchona, which turned out to be narcotine (Medical and Physical Society, 1838, p. 387). O’Shaughnessy, at the meting of the Medical and Physical Society of Calcutta, also exhorted his colleagues "resident in the most unhealthy parts of the country (and he specified Kyok Phoo, Akyab, Chittagong, Tamlook, Rungpore) be invited to give the narcotine a trial and to report results" (Medical and Physical Society, 1838, p. 387).

He also found that a resin "procured by acting on the dried hemp-plant with spirit of wine ... possesses the power of subduing the spasms of lock-jaw ... it also mitigates all the horrible symptoms of hydrophobia ..." (Asiatic Journal, 1839, p 101).

On 14 April 1837, on the occasion of Lord Auckland's fifth scientific party, in presence of Lord Auckland, Dr. O'Shaughnesy made some purely chemical experiments. “Dr. O’Shaughnessy showed the properties of carbonic acid, and its effects on flame and animal life. Carbonic oxide, caburet of hydrogen, and the olenant gases ... explained the principles of of the new galvanic battery, by Muller" (Lord Auckland's Fifth Scientic Party, 1837, p. 671).

As previously seen in the two cases of experiments on dogs and, also in the case enumerated above, what is at stake is animal life. It could be subjected to various experiments and the laws of nature could be explained through these experiments. Moreover, these experiments were usually performed with the "aided eye" (e.g. microscope) and these experiments could be reproduced and publicly demonstrated. The message was simple - hitherto existing naturehuman harmony was broken apart, nature could be mastered and used for the purpose of human being in an all-pervasive way. Another point of mention, since the time of Bentinck and Auckland, science was gaining state patronage. It was not merely an individual effort like the foundation of Hindu College or the Calcutta Madrasa.

O’Shaughnesy's first series of experiments using Indian hemp on both humans and animals "were published in the Transactions of the Medical and Psychiatric Society of California in 1842, where they generated considerable interest" (Crossbie, 2012, p 184). The Lancet published a report of his experiments on 18 cases of tetanus (New Remedy for Tetanus and Other Convulsive Disorders, 1840: 539-541). Indian hemp was also tried in cases of rheumatism. O'Shaughnessy also undertook to experiment with the application of galavanism to cure epilepsy (Bellingham, 1847, p. 101). "The salts of narcotine have been employed successfully as antiperiodics in intermittent ... sixty cases were treated, of which all but two were successful” (Dunglison, 1848, p. 428).

The figure of the "narcotine trial" by O'Shaughnessy is reproduced below from the Calcutta Monthly Journal (1838, No. LXVII).

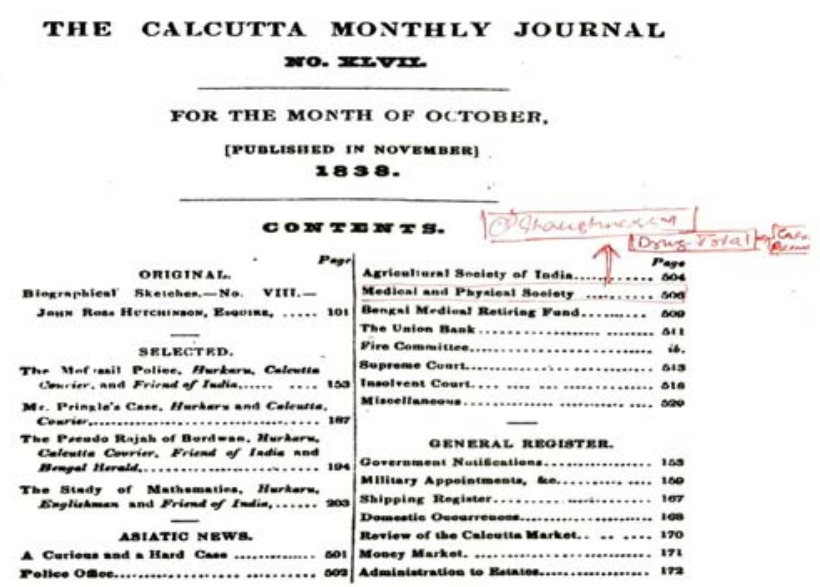




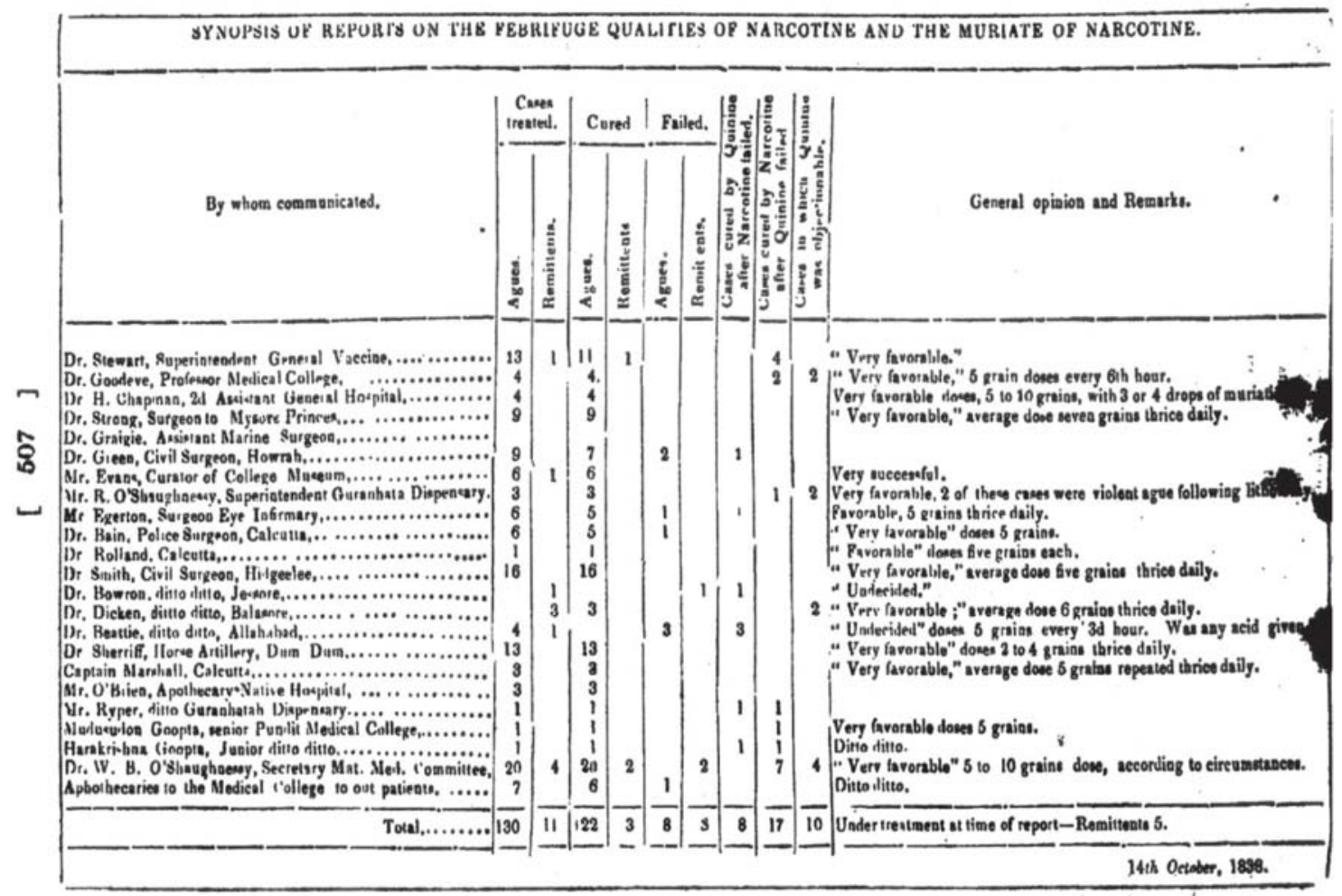

These experimentations made it comprehensible that the whole person was analyzable into pathological, microscopical and chemical sub-entities. "The sick-man became a collection of synchronized organs, each with a specialized function” (Jewson, 2009, pp. 623-624). As an overall outcome, the person of the patient was transformed into pathology inside the body and, in turn, became merely a number.

\section{Conclusion}

Spry believed that modern medicine embodied through the CMC must "exert a prodigious influence on the political condition of the British empire in the East” (Spry, 1837, p. 309). It happened through the objectification of patients who were erstwhile socially embedded persons. The paradigmatic shift occurred through the construction of case records. Case records were initially produced by the European hospitals. But, finally, the mechanism was sustained by the CMC and the dispensaries throughout India.
The CMC was also the first institution to work on the plan of "suitable accommodations" within "the precincts of the College" (GRPI, 1848, p. 100). Residential education was "considered one of the most essential and important features in the normal training of teachers in the schools of Germany, Holland, Switzerland, France, and, now, although to a more limited extent, of Great Britain” (GRPI, 1847, p. 82). Native medical medical students were to be accommodated within the precincts of the college to make them immune from "every influence resulting from ignorance, superstition, the prejudices of caste, and similar means of weakening the effects of the intellectual and moral training he is undergoing in our schools and colleges" (GRPI, 1847, p. 82). This was somewhat akin to the transference of patients to a noise-free environment of hospital mimicking the world of laboratory.

In a confident gleeful note, Sykes made it clear that "We have every reason to believe that the benevolent institution of Government in 
founding these institutions has been fully realized", and, as a result of it "future annual results will add to the intrinsic value of the dispensaries, which are so well adapted by their internal economy to obtain the confidence of the native inhabitants” (Sykes, 1847, p. 23).

A new vision of history of India was triumphantly put forward too. Sykes convincingly told about the benefits accrued from this new era of medical education dawning in India - "we shall have left a monument with which those of Ashoka, Chundra Goopta, or Shah Jehan, or any Indian potentate sink into insignificance" and, at the same time, "those of Auckland, as protector, and of Goodeve, Mouat, and others, as zealous promoter of scientific Native medical education shall remain embalmed in the memory of a grateful Indian posterity" (Sykes, 1847, p. 23). Notably, in this "new history", pragmatic and successful people like Auckland, Goodeve and Mouat found were only mentioned. W.B. O'Shaughnessy, the person with an original inquisitive mind and the spirit of free thinking, was excluded.

In later years, a few different voices came up from within the matrix of hegemonic hospital medicine. Bholanath Bose, a graduate from CMC and post-graduate from the UCL, observed, "as regards the state of the sick they are not diseases at all, but simply an expression of the actual state of the condition of sickness ... We are unable to perceive the relations of the symptoms with the actual state of the patient ... Why , then, it may be reasonably asked ... differ about disease?" (Bholanath Bose, 1877, pp. vi-vii). In his keen observation, disease and sickness are differentiated.

Was he incorporating the concept of svasthya of Indian connotation? Otherwise, was he going beyond the trend of the time - reducing patients into cases? He seems to dislocate the certainty and authority of modern medicine. He used a unique term "kyaitis" - a hybrid of the Sanskrit kaya, meaning body, and "itis" from modern pathology, meaning inflammation (Bose, 1877, p. 17)

Shital Chandra Chattopadhyaya seems to have lamented, "Without any encouragement from the King no scholarship can develop ... no one finds interest in the pursuit of knowledge when there is the lack of care and trust on behalf of the King (Chattopadhyaya, 1885: 14-15, p. 15). In such a trying situation Āyurveda had to incorporate and mimic modern anatomy, physiology, pathology and the mechanism of disease causation. Being uprooted from their social epistemological root, they had to contend, assimilate, replicate and talk in terms of modernity.

Such contesting epistemological trends tried to confront the hegemony of the new medicine. Though, quite often, they were contained within its matrix as they followed the same methods of modern medicine of knowing the body. Thus, including Ayurveda, they turned out to be a variant of modern medicine. They had to adopt the same method of case history, autopsy and clinical trials. To become modern, they had to recast themselves in the mold of hospital medicine and the new paradigm of keeping case records.

Case records became one of the benchmarks and referent for modern medicine engrafted on a soil being altogether different socially, economically, culturally an politically.

\section{BiBLIOGRAPHY}

Ackerknecht, Erwin H. Medicine at the Paris Hospital, 1794-1848, Johns Hopkins University Press, Baltimore 1967.

Adam, J. On the Epidemic Bronchitic Fever of Infants and Young Children, prevalent in Calcutta during the Rains, or Months of June, July, and August, of 1828. Transactions of the Medical and Physical Society of Calcutta, 4 (1828): 320-38 (p. 324). [Emphasis added].

Alavi, Seema. Islam and Healing: Loss and Recovery of an Indo-Muslim Medical Tradition 1600-1900, Permanent Black, New Delhi 2007, p. 98. For both 
the NMI and medical classes at the Sanskrit College see, S. N. Sen, Scientific and Technical Education in India, 1781-1900, Indian National Science Academy, New Delhi 1991.

Allbutt, T. Clifford. The Historical Relations of Medicine and Surgery to the End of the Sixteenth Century: An Address Delivered at the St. Louis Congressin 1904, Macmillan \& Co. Ltd., London 1905. Allbutt deals with the separation of medicine and surgery in full length.

American Ice, Calcutta Monthly Journal, XXVII (1837): 118-119.

Appendix I. To Second Report of Committeee upon the Fever Hospital and Municipal Improvements, Bishop's College Press, Calcutta 1848, p. 278.

Appendix C. Evidence Taken by the First Sub-Committee upon the Fever Hospital and Municipal Improvements, Bengal Military Orphan Press, Calcutta 1838, p. clvi. [Emphassis added]

Arnod, David, Colonizing the Body: State Medicine and Epidemic Disease in Nineteenth-Century India, University of California Press, Berkeley 1993, p. 53.

Asiatic Journal, XVII (1824): 400.

Asiatic Journal, 29, 114 (New Series, 1839): 101.

Balfour, Francis. A Collection of Treatises on the Effects of Sol-Lunar Influence in Fevers; with An Improved Method of Curing Them. Cupar, London 1815, p. 31. [Emphasis added]

Bhattacharya, Jayanta. Encounter in Anatomical Knowledge: East and West. IJHS, 43 (2008): 163-210.

Bhattacharya, Jayanta. Arrival of Western Medicine: Āyurvedic Knowledge, Colonial Confrontation and its Outcome. IJHS, 46 (2011): 63-108.

Bhattacharya, Jayanta and Deepak Kumar and Raj Sekhar Basu, (eds). Anatomical Knowledge and East-West Exchange. Medical Encounters in British India, Oxford University Press, New Delhi 2013, pp. 40-60 (p. 46).

Bellingham, O’Bryen. Observations on Aneurism, and its Treatment by Compression. John Churchill, London 1847, p. 101.

Berkowitz, Carin. Systems of display: the making of anatomical knowledge in Enlightenment Britain. British Journal of History of Science, 46.3 (2012): 129.
Bose, Bholanath. A New System of Medicine, Entitled Recognizant Medicine; or, the State of the Sick. J. \& A. Churchill, London 1877, pp. vi-vii.

Bose. Principles of Rational Therapeutics. J. \& A. Churchill, London 1877, p. 17.

Breton, P. On the Efficacy of the Bark of the Swietenia Febrifuga, as a Substitute For that of the cinchona. Medico-Chrirugical Transactions, 11, pt. 2 (1821): 310-329 (p.312). For a nice discussion on Swietentia febrifuga see, Chakrabarti, Pratik. Empire and Alternatives: Swietentia febrifuga and the Cinchona Substitutes. Medical History, 54, 1 (2010): 75-94.

Brett, F. H. A Practical Essay on Some the Principal Surgical Diseases of India. W. Thacker and Co., Calcutta 1840.

British Medicine in India. British Medical Journal, 1, 2421 (May 25, 1907): 1245-1253.

Calcutta Review, XIX (January-June 1843): xviii.

Calcutta Monthly Journal, Third Series, IV (1838): 270275.

Cassel, Eric J. The Nature of Suffering and the Goals of Medicine. New England Journal of Medicine, 306 (1982): 639-645 (p. 642).

Caution to the Public: Nux Vomica Bark sold in the bazaars, as the Rohun, or Swietenia Febrifuga. Indian Review and Journal of Foreign Science and the Arts, 1 (1837): 287-289 (p. 288).

Chakrabarti, Pratik. Materials and medicine: trade, conquest and therapeutics in eighteenth century. Manchester University Press, Manchester and New York 2010, p. 135.

Chattopadhyaya, Shital Chandra. Ayuveda Vaijnanik ki Avaijnanik? (Is Ayurveda Scientic or Non-Scientific). Cikitsa-Sammilani, 2 (1885): 14-15 (p. 15).

Chobanian, Aram V. The Hypertension Paradox - More Uncontrolled Disease despite Improved Therapy. New England Journal of Medicine, 361 (2009): 878-887 (p. 878).

Chuckerbutty, S. G. Iodide of Potassium in the Treatment of Aneurism. British Medical Journal (BMJ), 2, 81(1862): 61-64 and BMJ, 2, 82 (1862): 85-86.

Chuckerbutty. A Case of Amyloid Degeneration. BMJ, 1, 130 (1863): 680-81.

Chuckerbutty. A Singular Case of Epilepsy. Medical Times and Gazette, 5 (New Series, 1852): 406-408 (p. 408). 
Chuckerbutty. The Present State of Medical Profesion. BMJ, 2, 187 (1864): 109-12 (p. 111).

Chuckerbutty. The Present State of the Medical Profession in Bengal. BMJ, 186 (1864): 86-88

Cook, Harold J. Introduction. in W. F. Bynum, Anne Hardy, Stephen Jacyna, Christopher Lawrence, E.M. (Tilli) Tansey, The Western Medical Tradition, 1800 to 2000, pp. 1-6

Conwell, W. E. E. Observations Chiefly on Pulmonary Disease in India and an Essay on the Use of Stethoscope. Mission Press, Malaca 1829.

Crawford, D. G. A History of the Indian Medical Service 1600-1913. 2 vols, vol. II, Thacker Spink and Co., Calcutta 1914.

Crossbie, Barry. Irish Imperial Networks: Migration, Social Communication and Exchange in Nineteenth-Century India. Cambridge University Press, Cambridge and New York 2012.

Caraka Saṃhita, tr, P. V. Sharma, I, p. 306.

Curtis, Charles. An Account of the Diseases of India, as They Appeared in the English Flee, and in the Naval Hospital at Madras, in 1782 and 1783. W. Laing, Edinburgh 1807, p. xviii.

Dasgupta, S. N. A History of Indian Philosophy. 5 vols., II, Motilal Banarsidass, Delhi 1991.

Dickason, David G. The Nineteenth-Century Indo-American Ice Trade: An Hyperborean Epic. Modern Asian Studies, 25 (1991): 53-89

Dunglison, Robley. The practice of medicine: a treatise on special pathology and therapeutics. $3^{\text {rd }}$ edn., 2 vols, 2, Lee and Blanchard, Philadelphia 1848.

Edelstein, Ludwig, Ancient Medicine: Selected Papers of Ludwig Edelstein, Owsei Temkin and C. Lilian Temkin, (ed), Johns Hopkins University Press, Baltimore and London 1994, pp. 260-61.

Fischer-Tine, Harald. Low and Licentious Europeans: Race, Class and 'White Subalternity' in Colonial India. Orient BlackSwan, New Delhi 2009.

Fissel, Mary E. and French, Roger and Wear, Andrew (ed). The disappearance of the patient's narrative and the invention of hospital medicine. British Medicine in an Age of Reform, Routledge, London 1991, pp. 92109.

Fleming, John. A Catalogue of Indian Medical Plants and Drugs, Hindustani Press, Calcutta, 1810.
Gawande, Atul. Two Hundred Years of Surgery. New England Journal of Medicine, 366 (2012): 1716-1723

Gelfand, Toby. Gestation of the Clinic. Medical History, 26 (1981): 169-180.

General Report on Public Instruction, 1848, pp. 77-118.

Goodeve, H. H. Introductory Lecture, May 3, 1836. Calcutta Monthly Journal, Third Series - Vol. II (1836): 1926.

Gorman, Mel. Introduction of Western Science into Colonial India: the Role of the Calcutta Medical College. Proceedings of the American Philosophical Society, 132 (1988): 276-298.

Harrison, Mark. Medicine in an Age of Commerce and Empire: Britain and Its Tropical Colonies, 1660-1830. Oxford University Press, Oxford 2010, p. 4.

Harrison, Mark, Margaret Jones and Helen Sweet (eds). Introduction. From Western Medicine to Global Medicien: The Hospital Beyond the West, Orient BlackSwan, New Delhi 2009

Heister, Lawrence. A General System of Surgery in Three Parts. Containing the Doctrine and Management I. Of Wounds, Fractures, Luxations, Tumours, and Ulcers, of all Kinds. II Of the several Operations performed on all Parts of the Body. III. Of the several Bandages applied in all Operations and Disorders. W. Innys, London 1743

Herold, Marc H. Ice in the Tropics: the export of 'Crystal Blocks of Yankee Coldness' to India and Brazil,” Revista Espaco Academico, 126 (2011): 162-177

Hess, Volker and Mendelson, J. Andrew, Case and Series: Medical Knowledge and Paper Technology, 16001900. History of Science, 38 (2010): 287-314

Horstmanshoff, H. F. J. Galen and his patients in Ph. J. van der Eijk, H. F. J. Horstmanshoff and P. H. Schrijvers, (eds), Ancient Medicine in its Socio-Cultural Context, Rodopi, Amsterdam and Atlanta 1995, pp. 90-91.

Hunter, William. Two Introductory Lectures, Delivered by Dr. William Hunter, to His Last Course of Anatomical Lectures. J. Johnson, London 1784.

Jacyna, Stephen. Medicine in transformation, 1800-1849 in W. F. Bynum, Anne Hardy, Stephen Jacyna, Christopher Lawrence, E.M. (Tilli) Tansey, The Western Medical Tradition, 1800 to 2000, Cambridge University Press, Cambridge and New York 2006, pp. 11-110 (p. 53). 
Jaggi, O. P. Medicine in India: Modern Period. Oxfrod University Press, New Delhi 2011

Jewson, N. D. The disappearance of the sick-man from medical cosmology, 1770-1870. International Journal of Epidemiology, 38 (2009): 622-633. Reprinted from Sociology, 10 (1976): 225-244.

Johnson, James. The Influence of Tropical Climate on European Constitutions. Benjamin and Thomas Kite, Philadelphia, 1824

Kalpagam, U. Tempralities, History and Routines of Rule in Colonial India. Time and Society, 8 (1999): 141159

Kern, Stephen. Time and Medicine. Annals of Internal Medicine, 132 (2001): 3-9.

Lee, Richard V. Doctoring to the Music of time. Annals of Internal Medicine, 132 (2000): 11-17.

Lord Auckland's Fifth Scientic Party. Indian Review and Journal of Foreign Science and Arts, 1 (1837): 671. [Emphasis added]

MacLeod, Roy (ed.). Introduction. Disease, Medicine and Empire: Perspectives on Western Medicine and the Experience of European Expansion. Routledge, London and New York, 1988

Macpherson, J. Notes on Some Points of Indian Practice. London Medical Gazette, 2 (New Series, 1841): 546551.

Mazars, Guy. A Concise Introduction to Indian Medicine, Motilal Banarsidass, Delhi 2006, pp. 28-29.

Medical and Physical Society. Calcutta Monthly Journal, XXVII (1838): 387-388 [Emphasis added]

Meulenbeld, G. Jan. A History of Indian Medical Literature. 5 vols, IA, Egbert Forsten, Groningen 1999, p. 46. Therefore, no circumscribed meaning can be derived from the notion of the body in Âyurveda.

Meulenbeld. The Madhavanidāna With 'Madhukoúa', the Commentary by Vijayarakcita and ErikaGmhadatta (Chapters 1-10). Motilal Banarsidass, Delhi, 2008

Nakamura, Hajime. A Comparative History of Ideas. Motilal Banarsidass, Delhi 1992

Native Medical Institutions. Asiatic Journal and Monthly Register, New Series, Vol. 17, 68 (1835): 226.

New Remedy for Tetanus and Other Convulsive Disorders. Lancet, 2 (1840): 539-541.

O’Shaughnessy, R. and Paul F. Eve, (ed). Enormous tumour of the upper jaw successfully removed. A Collection of Remarkable Cases in Surgery, J. B. Lippincott and Co., Philadelphia 1857, pp. 138-142.

O’Shaughnessy W.B. On Narcotine as a Substitute for Quinine in Intermittent Fever. Lancet, 2 (1839): 606607. Also see Medical and Physical Society. Calcutta Monthly Journal, XLV (August 1838): 387-388.

Pickstone, John V. Commentary: From history of medicine to a general history of "working knowledges". International Journal of Epidemiology, 38 (2009): 646-649.

Porter, Roy. The Greatest Benefit to Mankind. W. W. Norton \& Company, New York and London, 1999.

Price, David (tr). Extracts from the Mualiját-i-Dárá-Shekohí, selected. Transactions of the Royal Asiatic Society of Great Britain and Ireland, III (1835): 32-56.

Rather, L. J. (tr). Disease, Life, and Man - Selected Essays by Rudolf Virchow, California University Press, Stanford and California,1958

Reiser, Stanley Joel. Technologies of Time Measurement: Implications at the Bedside and the Bench. Annals of Internal Mediicne, 132 (2000): 31-36

Report of the General Committee of Public Instruction... for the Year 1839-40

Report of the General Committee of Public Instruction of the Presidency of Fort William in Bengal for the Year 1836, Appendix 8

Richardson, Ruth. Death, Dissection and the Destitute. $2^{\text {nd }}$ edn, University of Chicago Press, Chicago and London, 2000

Risse, Guenter. Mending Bodies, Saving Souls: A History of Hospitals. Oxford University Press, New York and Oxford, 1999

Roberts, William. The Successful Use of Iodide of Potassium in the Treatment of Anerism. BMJ, 1, 101 (24 January 1863): 83-85.

Rules and Regulations of the Bengal Medical College, Office of the Bengal Government, Calcutta, 1844.

Rules and Regulations of the Bengal Medical College, Office of the Bengal Governement, Calcutta, 1849.

Sappol, Michael. A Traffic of Dead Bodies: Anatomy and Embodied Social Identity in Nineteenth-Century America. Princeton University Press, Princeton and Oxford,2004

Sarkar, Mohendralal. A Case of Hepatic Abscess. BMJ, 2, 184 (1854): 36-37. 
Sarkar, Sumit. Writing Social History. Oxford University Press, New Delhi, 2002

Sen, S N. Scientific and Technical Education, 1991

Seton-Karr, W. S. (ed). Selections from Calcutta Gazettes of the Years 1798, 1799, 1800, 1801, 1802, 1803, 1804, and 1805, Showing the Political and Social Condition of the English in India Sixty Years Ago. 4 vols, III, Calcutta 1868.

Southey, Robert. Letters from England. 3 vols, II, $3^{\text {rd }}$ edn, Longman, Hubert, Rees, Orme and Brown, London 1814

Spry, Henry H. Modern India, with Resources and Capabilities of Hindustan. Whittaker and Co., London 1837

Suśruta Saṃhita, ed \& tr, P. V. Sharma. 3 vols, I, Chaukhamba Visvabharati, Varanasi, 2004

Sykes, W. H . Statistics of the Government Charitable Dispensaries of India, chiefly in the Bengal and NorthWestern Provinces. Quarterly Journal of the Statistical Society of London, 10. 1(1847): 1-37

Temkin, Owsei. The Double Face of Janus and Other Essays in the History of Medicine. Johns Hopkins University Press, Baltimore 1977, pp. 487-496

Thapar, Romila. Time as A Metaphor of History: Early India. Oxford University Press, New Delhi, 2006

Thompson, E. P. Time, Work, Discipline and Industrial Capitalism. Past and Present, 38 (1967): 56-97

Third Report of the Committee Appointed by the Right Honourable Governor of Bengal for the Establismnet of A Fever Hospital, Calcutta Bishop's College Press 1847, pp. 63-68.

Transactions of the Medical and Physical Society of Calcutta, 4, 1829

Treatment of the Epidemic by A Mogul Physician, Asiatic Journal, VI (1818): 474.
Trohler, Ulrich, Gerard Jorland, George Weisz and Annick Opinel, (eds). Quantifying Experience and Beating Biases: A New Culture in Eighteenth-Century British Clinical Medicine. Body Counts: Medical Quantification in Historical and Sociological Perspective. McGill Queen's University Press, Quebec 2005, pp. 19-50 (pp. 26-27).

Tytler, John. The anis ul Mushrrahin or the Anatomist's Vade-Mecum, Education Press, Calcutta 1830

Van de Graaf, R. C. Some remarks on the revival of rhinoplasty in Europe in the early nineteenth century. Acta Otorhinolaryngol Ital., 29, 4 (2009): 226. Also see, Wujastyk, Dominik, Bynum, W. F. and Porter, Roy (eds). Indian Medicine. Companion Encyclopedia of the History of Medicine, ed., 2 vols., I, Routledge, London and New York 1993, pp. 755-778.

Watt, Charles (ed). The Chemist; or, Reporter of Chemical Discoveries and Improvements. 1 (1840): 156.

Williams, Monier (ed). Original Papers Illustrating the History of the Application of the Roman Alphabet to the Languages of India. Longman, Brown, Green, Longmans, and Roberts, London, 1859.

Webb, Allan. The Historical Relations of Ancient Hindu With Greek Medicine. J. C. Sheriff, Calcutta, 1850.

Wujastyk, Dominik. Interpreting the Image of the Human Body in Premodern India. International Journal of Hindu Studies, 13 (2009): 189-228.

Yates, William and Maclean, Charles. A View of Life; on the Principles Established in the Elements of Medicine, on the Late Celebrated John Browwn ... Cases in Illustrations, Chiefly Selected from the Records of their Practice, at the General Hospital, at Calcutta. Dover, 1801.

Zimmermann, Francis. The Conception of the Body in Ayurvedic Medicine: Humoral Theory and Perception. URL: http://ehess.philosophindia.org/philosophie/ index.php?id=84, accessed 21 June 2013. 